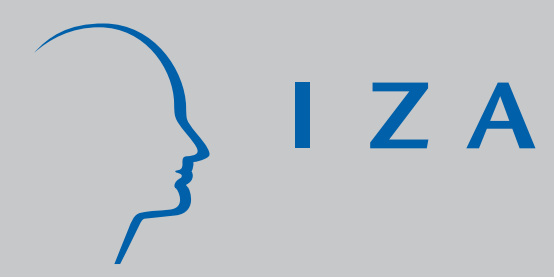

IZADP No. 2405

How Immigrants Fare Across the Earnings

Distribution: International Analyses

Barry R. Chiswick

Anh T. Le

Paul W. Miller

October 2006 


\title{
How Immigrants Fare Across the Earnings Distribution: International Analyses
}

\author{
Barry R. Chiswick \\ University of Illinois at Chicago \\ and IZA Bonn \\ Anh T. Le \\ University of Western Australia \\ Paul W. Miller \\ University of Western Australia \\ and IZA Bonn
}

\section{Discussion Paper No. 2405 \\ October 2006}

\author{
IZA \\ P.O. Box 7240 \\ 53072 Bonn \\ Germany \\ Phone: +49-228-3894-0 \\ Fax: +49-228-3894-180 \\ Email: iza@iza.org
}

Any opinions expressed here are those of the author(s) and not those of the institute. Research disseminated by IZA may include views on policy, but the institute itself takes no institutional policy positions.

The Institute for the Study of Labor (IZA) in Bonn is a local and virtual international research center and a place of communication between science, politics and business. IZA is an independent nonprofit company supported by Deutsche Post World Net. The center is associated with the University of Bonn and offers a stimulating research environment through its research networks, research support, and visitors and doctoral programs. IZA engages in (i) original and internationally competitive research in all fields of labor economics, (ii) development of policy concepts, and (iii) dissemination of research results and concepts to the interested public.

IZA Discussion Papers often represent preliminary work and are circulated to encourage discussion. Citation of such a paper should account for its provisional character. A revised version may be available directly from the author. 


\section{ABSTRACT}

\section{How Immigrants Fare Across the Earnings Distribution: International Analyses ${ }^{*}$}

This paper applies the quantile regression methodology to the study of the determinants of the distribution of earnings among the native born and immigrants in the United States and Australia. The analysis for immigrants is performed separately for those from Englishspeaking and non-English speaking origins. Using Census data, the quantile regressions permit the measurement of the partial effect of explanatory variables (such as schooling and experience) and the native born-immigrant earnings differential at the different deciles of the earnings distribution. Among other findings, the effects on earnings of schooling and labor market experience are shown to increase at higher deciles. The native-immigrant earnings gap varies by decile, and in particular increases in the U.S. at higher deciles. Minimum wages in the U.S. appear to compress earnings at low deciles, while the Australian minimum (administered) wage system appears to compress earnings across the distribution of earnings.

JEL Classification: J15, J24, J31, F22

Keywords: immigrants, earnings distributions, rates of return, quantile regression

Corresponding author:

Barry R. Chiswick

Department of Economics

University of Illinois at Chicago

601 South Morgan Street

Chicago, IL 60607-7121

USA

E-mail: brchis@uic.edu

\footnotetext{
* We thank Derby Voon for research assistance and Gib Bassett for helpful discussion. Chiswick acknowledges research support from the Institute of Government and Public Affairs, University of Illinois. Miller acknowledges financial assistance from the Australian Research Council.

Note: The data used in this paper are the United States 2000 Census of Population, PUMS file, one percent sample and the Australian 2001 Census of Population and Housing, one percent sample.
} 


\section{HOW IMMIGRANTS FARE ACROSS THE EARNINGS DISTRIBUTION: INTERNATIONAL ANALYSES}

\section{INTRODUCTION}

Most of the research into the earnings situation of the foreign born has compared their mean earnings to that of the native born, when other variables are held constant, and placed emphasis on the role of the standardizing factors in the earnings equation. Studies of this type for the U.S. labor market generally report that the foreign born experience considerable earnings disadvantages. In 2000 adult male immigrants had hourly earnings, on average, around 17 percent less than the native born. Once account is taken of differences between the birthplace groups in their productivity-related characteristics, this gap in mean hourly earnings is narrowed, but still remains at around 8 percentage points among recent arrivals. ${ }^{1}$

Butcher and DiNardo (2004), on the other hand, depart from this conventional focus on the conditional mean by estimating the earnings distributions of the native born and the foreign born using non-parametric methods. This paper extends the line of enquiry proposed by Butcher and DiNardo (2004), using 2000 U.S. Census data, and using semi-parametric techniques. A quantile regression approach is used. ${ }^{2}$

Quantile regression facilitates a full characterization of the conditional distribution of earnings, and has the potential to offer advantages in the study of inequality when exogenous variables influence parameters of the conditional distribution of earnings other than the mean. ${ }^{3}$ The approach allows the increments in earnings

\footnotetext{
${ }^{1}$ Calculations based on the 2000 US Census, 1 percent Public Use Microdata Sample.

2 Machado and Mata (2005, p. 451) note that “...resorting to a parametric model is necessarily restrictive. Yet this weakness buys some additional information”. This additional information is essentially that associated with the quantile regression coefficients that are the focus of the discussion in Sections IV and V.

3 Two distributions may have the same mean, but differ in other parameters of the distribution, such as variance (inequality), skewness (asymmetry) and kurtosis (peakedness), which can be measured by the second, third and fourth moments about the
} 
associated with the conventional determinants of earnings to be compared across the percentiles of the distribution of earnings. For example, the increments in earnings associated with years of schooling, or years since migration among the foreign born, can be compared for low wage (low skilled) workers and high wage (high skilled) workers. These comparisons may provide a more informative framework to assist understanding the labor market processes responsible for the foreign-born/native-born differential in conditional mean earnings analyzed in past research.

The structure of the paper is as follows. Section II presents a brief review of the literature, commencing with the conventional studies (using OLS) of the differences in mean earnings of the native born and the foreign born that are largely based on the decomposition developed by Blinder (1973) and Oaxaca (1973), and moving through to the recent work by Butcher and DiNardo (2004) that estimates the earnings distributions (using a non-parametric approach) of these birthplace groups. Details of the quantile regression approach adopted in the current analysis are presented in Section III. Section IV discusses results from models estimated using data from the 2000 U.S. Census. Section V presents a comparative analysis for Australia, a labor market often cited as having more institutional rigidities than the U.S. labor market, and therefore offering immigrants with a job greater wage protection, but being associated with higher unemployment and less on-the-job training (Miller and Neo (2003), Antecol et al. (2005)). This comparison may provide insights regarding the extent to which the findings for the U.S. are driven by institutional features. A summary and conclusion are offered in Section VI.

\section{LITERATURE REVIEW}

There has been extensive research into the native/immigrant earnings differential in the U.S. labor market. The typical approach to modelling the native/migrant earnings differential is based on assessing the difference in the mean earnings between the two groups. It has the advantage of allowing simple modelling of the earnings differential, and as argued by Yuengert (1994, p. 74), the sample mean "most exactly signifies what

mean, respectively. OLS will not tease out these differences, but quantile regression can assist in this regard. 
we mean when we say 'immigrants do relatively well' or 'immigrants do relatively poorly'”. Estimation of the determinants of the mean earnings of the native born and the foreign born using OLS facilitates use of the decomposition developed by Blinder (1973) and Oaxaca (1973), thereby providing an informative framework for analysis. Within this framework, the research has attempted to quantify the importance to the earnings gap of factors such as immigrants' skills, including schooling, labor market experience and language. An example of this research is Daneshvary (1993), who applied the Blinder/Oaxaca decomposition in a study of the earnings differential between native born and foreign born workers with college degrees. ${ }^{4}$ Daneshvary (1993) shows that the gross earnings differential for highly educated native born and immigrant workers is only around four percent. Taking account of differences in productivity-related characteristics between these groups actually widens the native born/immigrant earnings gap by three percentage points.

Extensions to this work have considered the role of institutions, immigrant selection, motive for migration and functional form. The importance of the composition of the immigrant intake is investigated by Antecol et al. (2003). They compare immigrants' educational attainment, language proficiency and earnings for Australia, the U.S. and Canada. The native born/immigrant differential in mean earnings among recent arrivals in the U.S. is larger than in Canada, and much larger than in Australia. Among longer-term settlers, however, there are smaller differences in the mean earnings of the native born and immigrants for the U.S. and Canada compared to that in Australia. Standardization for age, education and language proficiency reduces that apparent disadvantage of immigrants in the U.S., and this is in large part due to the low level of educational attainment among Latin American immigrants to the U.S., particularly those from Mexico. When these immigrants are excluded from the statistical analysis, the native/immigrant earnings gap declines further for U.S. immigrants, resulting in their

\footnotetext{
${ }^{4}$ This is a group that Daneshvary (1993) argued was likely to have a greater international transferability of their formal schooling. The empirical results support this conjecture, as the returns to education and US labor market experience for immigrants were not significantly different from the respective returns for the native born.
} 
relative mean earnings position comparing favorably with that of most arrival cohorts in Canada and Australia.

A study that extends the analysis beyond the general native born/immigrant earnings differential is Cortes (2004), who examines differences in human capital and earnings between newly arrived refugees and economic immigrants to the U.S. Cortes (2004) shows that while refugees initially have lower mean earnings than economic immigrants, they have a relatively faster earnings growth. Among immigrants who arrived in the U.S. between 1975 and 1980, for example, male refugees had mean earnings 17 percent less than comparable male economic immigrants in 1980. By 1990 this group of refugees was earning 3 percent more than otherwise comparable economic immigrants. Labor supply was identified as the main contributor to the improvement in refugees' relative position, with two thirds of the improvement being linked to relative increases in their annual hours worked, and one-third to relative increases in their annual weeks worked. The same patterns were reported among female immigrants, although among those who worked the earnings disadvantage of female refugees in 1980 was a minor 1 percentage point. ${ }^{5}$

A possible shortcoming of these conventional approaches to the study of immigrants' earnings is that they do not take into account differences in characteristics and outcomes between immigrants and the native born at various points in the earnings distribution. Butcher and DiNardo (2004) attempt to overcome this limitation by using non-parametric methods to estimate the earnings distributions of the native born and foreign born. Their density estimates were used to analyze changes in the earnings distributions of recent immigrants and the native born in the U.S. between 1970 and 1990, with the non-parametric approach permitting the identification of the parts of the distribution of earnings where the foreign born are most disadvantaged. Butcher and DiNardo (2004) show that neither the native born/immigrant earnings differential, nor the factors that contribute to this, are uniform across the earnings distribution. Summaries of

\footnotetext{
${ }^{5}$ Butcher and DiNardo (2002) argue that the minimum wage plays a large role in shaping the wage distribution for women. It presumably could be associated with a compression of the wage differentials among the lowest paid groups, such as recently arrived female immigrants.
} 
the distributions for the $25^{\text {th }}, 50^{\text {th }}$, and $75^{\text {th }}$ percentiles were presented. When 1970 prices were used to value skills, the relative importance of changes in skills and changes in the structure of earnings varied across the earnings distribution, with changes in skills being more important among the less well paid, for both males and females. ${ }^{6}$

The contribution by Butcher and DiNardo (2004) suggests that research into the native born/immigrant earnings differential should consider the entire earnings distribution rather than focusing on the differential at the mean. This can be accomplished through the quantification of the impact of the determinants of earnings across the distribution of earnings. The quantile regression approach is a method that is suited to this purpose.

\section{QUANTILE REGRESSION}

Following Buchinsky (1998), and assuming $\left(y_{i}, x_{i}\right), i=1, \ldots, n$ is a sample of the population, $y_{i}$ is the dependent variable and $x_{i}$ is the $k$ by 1 vector of explanatory variables, a simple quantile regression model can be written as:

$y_{i}=x_{i} \beta_{\theta}+u_{\theta_{i}}$, Quant ${ }_{\theta}\left(y_{i} \mid x_{i}\right)=x_{i} \beta_{\theta}$,

where Quant ${ }_{\theta}\left(y_{i} \mid x_{i}\right)$ refers to the conditional quantile of $y_{i}$, conditional on the vector of the explanatory variables $x_{i}$, and $\theta \in(0,1)$. It is assumed that $\operatorname{Quant}_{\theta}\left(u_{\theta i} \mid x_{i}\right)=0$.

The quantile regression estimates are achieved by minimizing the weighted sum of the absolute value of the errors (see Bedard, 2003). In other words, the $\theta^{\text {th }}$ conditional quantile regression estimator for $\beta$ is obtained by:

$$
\min _{\beta}\left[\sum_{\left\{i: y_{i} \geq x_{i} \beta\right\}} \theta\left|y_{i}-x_{i} \beta\right|+\sum_{\left\{i: y_{i}<x_{i} \beta\right\}}(1-\theta)\left|y_{i}-x_{i} \beta\right|\right] .
$$

A major benefit of quantile regression is that it allows for the impact of explanatory variables on the dependent variable to be analyzed along the total distribution of a data sample. For example, the impact of schooling or immigrant status at the $10^{\text {th }}$

\footnotetext{
${ }^{6}$ Butcher and DiNardo (2004) show that the results are sensitive to the choice of base period. This reinforces comments made by Yuengert (1994), among others.
} 
percentile of the conditional log earnings distribution might be examined, and compared with the impacts of the variables at the median, $90^{\text {th }}$ or other percentiles of the log earnings distribution, holding all other variables constant. Eide et al. (2002) argue that a focus on the tails of the distribution rather than on the mean may be more appropriate in some situations, such as in their study of the effects of secondary school quality on earnings. In the study of immigrant earnings, the concentration of immigrants in the U.S. among the least skilled, and among the most skilled, suggests that the quantile regression approach may have merit.

Moreover, Butcher and DiNardo (2004), Miller and Neo (2003) and Antecol et al. (2005) have drawn attention to the effects of minimum wages on the native born/immigrant earnings comparisons. These effects would be expected to be more apparent when the left-hand tail of the distribution of earnings is considered than elsewhere in the earnings distribution.

For these and other reasons, quantile regression has been increasingly used in the labor economics field. ${ }^{7}$ For example, Garcia et al. (2001) and Sakellariou (2004) have used this methodology to examine gender wage effects, Eide et al. (2002) and Martins and Pereira (2004) have used it to study the rates of return to education, while Nielsen and Rosholm (2001) and Mueller (1998) study public/private sector wage differentials using a quantile regression approach. Applications to the study of scholastic achievements include Eide and Showalter (1998) and Bassett et al. (2002). The research reported below extends the scope of the applications to the immigrant labor market.

\section{ESTIMATES FOR THE U.S.}

\footnotetext{
${ }^{7}$ Buchinsky (1998) points out two other advantages of the quantile procedure. First, as quantile regression is based on a weighted sum of absolute deviations, the approach gives a robust measure of location on the distribution scale. In turn, this ensures that the estimated coefficients on the explanatory variables are not sensitive to outlier observations in the sample. Second, when the error term in the regression is of a nonnormal distribution, the estimates obtained from quantile regression may be more valid than those obtained using OLS. Various extensions of this quantile regression approach are covered in Eide et al. (2002) and Buchinsky (1998).
} 
The data for the estimations presented in this section are for 25-64 year old men from the 2000 U.S. Census of Population, Public Use Microdata Sample (1 percent sample). Both the native born and the foreign born are considered. Within the foreign born sample, immigrants from English-speaking countries are distinguished from those from non-English-speaking countries, as past research has shown that the labor market outcomes of these groups differ appreciably. ${ }^{8}$

Figure 1 presents the distribution of log hourly earnings for the native born, the foreign born from non-English-speaking countries, and the foreign born from Englishspeaking countries. The distribution of log hourly earnings for the native born (the solid line) is centered around 2.79 (the equivalent of $\$ 16.28$ per hour). It is presented here to provide a benchmark against which the distributions for the foreign born can be evaluated.

The distribution of log hourly earnings for the foreign born from Englishspeaking countries (the thin broken line) is less peaked than the distribution for the native born. ${ }^{9}$ It is to the left of that for the native-born over the lower-third of the distribution. The foreign born from English-speaking countries have a slightly greater relative frequency at the upper end of the range of earnings. Being a foreign-born person from an English-speaking country apparently means different things at different parts of the distribution of earnings.

The distribution of log hourly earnings for the overseas born from non-Englishspeaking countries (the thick broken line) is centered at a lower level of log earnings-at around 2.53 (the equivalent of $\$ 12.55$ per hour). It is to the left of the distribution for the native born, though the differences between the distributions are less apparent at very low and very high earnings. Hence, the impact of being a foreign-born worker from a nonEnglish-speaking country appears from this initial assessment to be far more pronounced across the middle percentiles of the earnings distribution than it is at the two tails.

\footnotetext{
${ }^{8}$ The main English-speaking countries are the UK, Ireland, Canada, Australia, New Zealand and the English-speaking Caribbean islands.

${ }^{9}$ The "peakedness" of a distribution, measured by the fourth moment about the mean, is referred to as kurtosis.
} 
The differences across the birthplace groups in the earnings distributions presented in Figure 1 can be quantified using OLS and quantile regressions, with an estimating equation that has only two regressors, dichotomous variables for immigrants from English-speaking countries (ENG) and for immigrants from non-English-speaking countries (NENG).

Estimation of this model using OLS gives the difference in the mean hourly earnings of these birthplace groups as +1 percent for ENG and -20 percent for NENG, compared to the native born.

Quantile regressions, estimated at each decile, show, however, that the difference between the earnings of the foreign born and the native born varies across the earnings distribution. ${ }^{10}$ The differences at the first decile are -0.12 , or 12 percent lower earnings, for the foreign born from ENG, and -0.26 (i.e., 26 percent lower earnings) for the foreign born from NENG. The earnings disadvantage of the foreign born from ENG widens when the focus is on the second decile, but becomes progressively smaller as higher deciles are considered. Indeed, beyond the $6^{\text {th }}$ decile, the ENG birthplace group actually has higher earnings than the native born.

Among the foreign born from NENG, the birthplace earnings differential at the $2^{\text {nd }}, 3^{\text {rd }}, 4^{\text {th }}$ and $5^{\text {th }}$ deciles is greater than that which prevails the $1^{\text {st }}$ decile. It is close to a 30 percent earnings disadvantage for the NENG between the $2^{\text {nd }}$ and $4^{\text {th }}$ deciles. Moreover, up to around the $7^{\text {th }}$ decile, this differential is greater than that found from the comparison of the means. And while the NENG birthplace group has relatively low earnings in the upper deciles, the extent of the disadvantage is less than that found in the comparison of the mean earnings of the NENG and native born groups.

The smaller earnings gap at the first decile compared to that at the $2^{\text {nd }}$ to $5^{\text {th }}$ deciles for the foreign born from non-English-speaking countries may be linked to minimum wages that compress the left-hand tail of the earnings distribution. Institutional explanations for immigrants' relative wage outcome are considered in detail below.

10 The quantile regressions reported here are estimated only at each decile, as the uniformity of the patterns indicated that little extra information would be gained through examining additional quantiles. 
Figure 2 illustrates these patterns. Clearly a focus on means masks considerable variation in the birthplace earnings differential across the distribution of earnings.

The foreign born differ from the native born in a number of ways that may account for this variation. For example, the mean level of education for the foreign born is almost two years less than that of the native born, though the foreign born are more concentrated in the tails, particularly that for low levels of education, than is the case for the native born. ${ }^{11}$ The foreign born also have lower levels of proficiency in English, which may account for the relatively low earnings of the foreign born from NENG. ${ }^{12}$

The multivariate analyses of the variations in log hourly earnings presented below take account of these differences in the productivity related characteristics of the foreign born and native born. The specification of the estimating equation is standard, including years of education, labor market experience and its square, marital status, region of residence, a dichotomous variable for reporting black as the racial origin, the number of years the foreign born have lived in the U.S. (in quadratic form) and information on English proficiency. Two dichotomous variables for English proficiency are used, the first for those who speak a language other than English at home and speak English "Very Well” or "Well”, and the second for those who speak a language other than English at home and speak English either "Not Well” or "Not at All”. ${ }^{33}$ The benchmark language group is those who speak only English at home. The variables are defined in detail, and the means and standard deviations are reported, in Appendix A.

Tables 1, 2 and 3 contain the regression results for the native born, immigrants from English-speaking countries, and immigrants from non-English-speaking countries, respectively. The first column in each Table lists results obtained using OLS; the

\footnotetext{
${ }^{11}$ While only 5 percent of the native born have 10 or fewer years of schooling, 28 percent of the foreign born have these levels of schooling. 10 percent of the native born have more than 16 years of schooling, compared to 13 percent of the foreign born.

12 Butcher and DiNardo (2002) show that a large part of the earnings gap between nativeborn and foreign-born workers can be attributed to differences in their characteristics, and this is more important in the lower deciles of the earnings distribution.

13 The choice of regressors in based on consistency with past research while providing a reasonable basis for the cross-country comparisons provided in the following Section.
} 
remaining are for each decile from the quantile regression approach. These coefficients are estimated fairly precisely (i.e., the standard errors are relatively small), though this might be expected given the sample sizes.

The conventional estimate of the return to schooling for the native born, obtained using OLS (Table 1, column 1), is 9.9 percent. An additional year of labor market experience for the native born in the OLS analysis is shown to increase mean earnings by 1.9 percent, when evaluated at 10 years of experience. Estimates of the returns to schooling and experience of these magnitudes are typical when the focus is on the conditional mean. The quantile regression analyses, however, show that the increments in earnings associated with these skills among the native born vary across the earnings distribution. Moreover, the quantile regression results display the same patterns in the earnings increments associated with these skills as have been reported in recent research for other countries. For example, education has a smaller impact on earnings at the lower deciles (of 8 percent) than it has at the upper deciles (of 12 percent) of the earnings distribution. ${ }^{14}$ An alternative way of expressing this is that if education on average enhances earnings, a highly educated person in the bottom decile must, by definition, have much lower earnings than would be predicted, and the earnings difference between the highly educated and those with little education in this decile must be compressed. Martins and Pereira (2004) argue there are three possible explanations for the finding: it is a consequence of over-education which impacts more on the bottom deciles, of ability as an omitted variable being of greater importance among the better educated, and differences in field of study or school quality that are positively related to years of schooling.

Similarly, the returns to experience for the native born are lower across the first few deciles of the distribution of earnings than they are across the upper deciles of the distribution of earnings. For example, when evaluated at 10 years of experience, the increment in earnings with experience is 1.4 percent at the first decile, 1.8 percent at the second decile, and rises monotonically to 2.4 percent at the ninth decile. That is, when

${ }^{14}$ Martins and Pereira (2004), based on quantile regression for 16 countries, show that returns to education are higher for the more skilled workers. 
employed in low-wage jobs, the upward mobility gained through additional years of labor market activity is far less than that gained through extra years of labor market activity when employed in high-wage jobs. In other words, career paths are flatter among lowpay jobs than among high-pay jobs.

The effects of education and labor market experience on earnings for immigrants from English-speaking countries and non-English-speaking countries are similar to those described for the native born. They are depicted in Figures 3 and 4.

Figures 3 and 4 show that, like the native born, skilled (high wage) immigrant workers achieve more through additional years of education and labor market experience than their unskilled (low wage) counterparts. ${ }^{15}$ However, for these forms of human capital, immigrants from non-English-speaking countries have far lower payoffs to human capital skills at each decile of the earnings distribution than immigrants from English-speaking countries. In turn, immigrants from English-speaking countries have lower payoffs than the native born at each decile, with the exception of the increments in earnings associated with experience at the upper deciles. Consequently, the greatest increase in earnings associated with schooling for immigrants from non-English-speaking countries is 6.6 percent at the $9^{\text {th }}$ decile, and this falls well short of the lowest increase in earnings associated with schooling for the native born (the 8.2 percent recorded at the $1^{\text {st }}$ decile). Similarly, the greatest increase in earnings associated with labor market experience (evaluated at 10 years) for immigrants from non-English-speaking countries is 1.17 percent (at the $9^{\text {th }}$ decile), and this is below the lowest increase in earnings associated with labor market experience for the native born, of 1.39 percent ( $1^{\text {st }}$ decile).

The estimated coefficients for several demographic variables do not vary greatly across the deciles of the distribution of earnings for particular birthplace groups. For example, the estimated negative effect of a black racial origin varies only between 9 and 13 percent across the deciles of the earnings distribution for the native born, while the

${ }^{15}$ The OLS estimates of the payoff to education are 9.9 percent, 7.2 percent and 5.2 percent, respectively, for the native born, immigrants from English-speaking countries and immigrants from non-English-speaking countries. The payoff to labor market experiences (pre-immigration in the case of the foreign born), evaluated at 10 years, for these three birthplace groups are 1.85 percent, 1.62 percent and 0.28 percent, respectively. 
earnings disadvantage for black immigrants increases as higher deciles of the earnings distribution are considered. Living in a metropolitan area is associated with between 19 and 21 percent higher earnings for the native born. The metropolitan area variable displays considerable variation, in both statistical significance and numerical impact, across the earnings distributions for immigrants from English-speaking countries. Relatively few of these immigrants, however, live outside the metropolitan areas. Living in the South is typically associated with between 7 and 10 percent lower earnings.

The years the foreign born have spent in the U.S., controlling for total labor market experience, are associated with higher earnings for immigrants from non-Englishspeaking countries, but not, in general, for immigrants from English-speaking countries. The latter effect is consistent with the high degree of the transferability to the U.S. labor market of the pre-immigration skills of the ENG immigrants.

Among immigrants from non-English-speaking countries, the increases in earnings with duration of residence are greater in the lower deciles of the earnings distribution than they are in the upper deciles of the earnings distribution. Hence, evaluated at 10 years of residence in the U.S., an extra year in the U.S. is associated with increments in earnings of one percent or more across the first five deciles, and with much lower changes in earnings in the top two deciles. The quantile regression results appear to be a reflection of the general finding from the immigrant adjustment literature that the greatest post-arrival gains in relative earnings are recorded by the immigrants with relatively low earnings at arrival (see Duleep and Regets (1996)(1997)). ${ }^{16}$

The estimates presented in Tables 1 to 3 may be used to quantify the birthplace earnings differential using a decomposition analogous to that developed by Blinder (1973) and Oaxaca (1973). As with the study of the difference in mean earnings using OLS and

16 The analysis of immigrant adjustment at a particular quantile is problematic, as the adjustment phenomenon will presumably move an immigrant to a higher part of the skills distribution (see Butcher and DiNardo (2004, p.115)). Similarly, Buchinsky (1998, p. 98) notes that the interpretation of the coefficients in quantile regression as the marginal change in the $\theta^{\text {th }}$ conditional quantile due to a marginal change in the independent variable “...does not imply that a person who happens to be in the $\theta^{\text {th }}$ quantile of one conditional distribution will also find himself/herself at the same quantile had his/her $x$ changed”. 
the Blinder/Oaxaca decomposition, this disaggregated analysis may provide a more flexible assessment of the birthplace earnings differential than that obtained from the inclusion of the dichotomous birthplace variables in the model estimated on data pooled across birthplace groups. The estimates described in Figure 3, in particular, suggest that this may be important. Hence, the gap between the payoff to schooling for the native born and the foreign born rises with the decile of the distribution of earnings. Compared to the native born, the gap is 1.4 percentage points at the first decile for immigrants from English-speaking countries, and 2.5 percentage points for this birthplace group at the $9^{\text {th }}$ decile. For immigrants from non-English-speaking countries, it is 4.8 percentage points at the $1^{\text {st }}$ decile, and 5.2 percentage points at the $9^{\text {th }}$ decile.

There are several methods that could be employed in the analysis (see Montenegro (2001), Machado and Mata (2005), and Albrecht et al. (2003)). A method based on Albrecht et al. (2003) is adopted here. This procedure is based on the characteristics of individuals who are in each of the quantiles of the wage distribution rather than on the average characteristics of the entire sample (as in Montenegro (2001) and Drolet (2002)). The calculations are done by first drawing random samples (of 100 with replacement) from the native born and foreign born databases (separately for immigrants from ENG and NENG). This is followed by sorting the observations by earnings in order to get an observation for each percentile. These steps are then repeated (500 times) before obtaining the average characteristics for each quantile of interest. The standardized earnings gap at each quantile can then be computed as $\left(\beta_{N B}^{Q}-\beta_{F B}^{Q}\right) \bar{X}_{N B}^{Q}$ or $\left(\beta_{N B}^{Q}-\beta_{F B}^{Q}\right) \bar{X}_{F B}^{Q}$ or as an average of these calculations, where $\beta_{N B}^{Q}$ and $\beta_{F B}^{Q}$ are the estimated quantile regression coefficients for the quantile of interest, and $\bar{X}_{N B}^{Q}$ and $\bar{X}_{F B}^{Q}$ are the mean characteristics of the native born and the foreign born, respectively, at that quantile. ${ }^{17}$ The latter magnitude, $\left(\beta_{N B}^{Q}-\beta_{F B}^{Q}\right) \bar{X}_{F B}^{Q}$, appears to be what most have in mind when talking about an immigrant earnings differential, and it is presented in Figure 5.

17 This decomposition is subject to the standard index number problem and other weaknesses of the Blinder (1973) decomposition (see Le and Miller (2004) for the relevant discussion). 
Figure 5 indicates that the earnings disadvantage of immigrants from NENG is slightly less at the lower deciles of the earnings distributions than it is across the middle of the earnings distribution. The relatively superior performance of the less-skilled could, as argued above, be associated with minimum wages, though the fact that this operates over about one-quarter of the earnings distribution may suggest that other forces are at work. The earnings disadvantage for this birthplace group does not deviate much from the estimate obtained using OLS up to the $6^{\text {th }}$ decile. Beyond this point in the earnings distribution, the earnings disadvantage obtained using the quantile regression approach is only one-half of the estimate obtained using OLS.

Immigrants from ENG countries do relatively well across the earnings distribution according to the Figure 5 information. There is little change in their relative position (of essentially no net advantage/disadvantage) across the first three deciles of the earnings distribution, after which they are depicted as having an earnings advantage which rises with the decile under consideration. For deciles below the $6^{\text {th }}$, the earnings differential obtained from the quantile regression approach is less than that indicated using OLS, while for the $6^{\text {th }}$ and higher deciles; the earnings differential is higher than that indicated using OLS.

The analyses reported above were repeated using annual earnings as the dependent variable. Minimum wages and other institutional rigidities should compress hourly wages, but increase the inequality of annual earnings because of the increased inequality in hours worked per year. Figure 6 provides information on the standardized annual earnings differentials of the foreign born adult males by nativity and by decile of the annual earnings distribution. ${ }^{18}$ The data for adult male immigrants from Englishspeaking countries in Figure 6 mirror quite well the information on hourly wages for this birthplace group in Figure 5. However, as this group generally does at least as well as, and usually much better than, the native born in the U.S. labor market, this might be expected. For adult male immigrants from non-English-speaking countries, however, the information on annual earnings in Figure 6 differs from that for hourly earnings in Figure

${ }^{18}$ Figures displaying the payoffs to education and experience by decile of the annual earnings distribution are very similar to Figures 3 and 4 that are based on the impacts on hourly earnings. 
5. There are two main differences. First, the disadvantage for immigrants from nonEnglish-speaking countries is greater when the focus is on annual earnings (on average, an 18 percent disadvantage) than when the focus is on hourly earnings (on average, a 12 percent disadvantage). In other words, there is greater inequality in annual earnings than in hourly earnings. Second, the standardized annual earnings disadvantage of immigrants from non-English-speaking countries is reasonably uniform across the earnings distribution. The only disparity of any note from that recorded for the conditional mean using OLS is the relatively superior outcome for those in the second decile of the distribution.

These analyses show clearly that being an immigrant in the U.S. labor market means different things at various parts of the earnings distribution, particularly when the focus is on hourly wages. These patterns may be associated with the minimum wage or union wage floors, which compress the left-hand tail of the earnings distributions. The payoffs to labor market experience and education appear to be less at the lower quantiles where minimum wages may be important.

\section{RESULTS FOR AUSTRALIA}

The patterns of effects across the wage distribution for the U.S. suggest that it may be instructive to compare this quantile regression analysis with a similar analysis for Australia — a labor market associated with a far higher degree of institutional wage setting (see Miller and Neo (2003), Antecol et al. (2005)). Antecol et al. (2005, p. 15), for example, note that "In 1990, Australia was ranked first (tied with Austria, Belgium, Finland, Norway, Portugal and Sweden) among 19 countries in bargaining centralization by the OECD”. This is argued by Miller and Neo (2003) to offer employed low-wage immigrants in Australia a degree of wage rate protection, and is reflected in findings reported in Antecol et al. (2005) to the effect that Australia has a more compressed wage distribution than the U.S. Of importance to this study is the fact that the wage setting system in Australia establishes a plethora of "award wages", and not just a single, minimum safety net. These award wages affect workers across the wage distribution. Accordingly, if institutional factors are responsible for the features of the quantile regression analysis across the first few deciles of the earnings distribution in the U.S., 
then similar features might be expected in Australia, with greater intensity and across much more of the earnings distribution.

The analyses for Australia are based on the 2001 Australian Census of Population and Housing (see Australian Bureau of Statistics (2003)). As far as possible, the variables have been defined in a similar way as in the analysis for the U.S. ${ }^{19}$ The income data for Australia are for weekly income, and both these data and that for hours worked per week are collected in categorical form. ${ }^{20}$ Mid-points have been used to form a continuous variable. The broad upper open-ended categories appear to affect the estimates in the upper deciles, though the uniform pattern in the results suggests this does not impact unduly on the findings.

Tables 4 to 6 presents a comparison set of quantile regression results for the Australian labor market. These results can be compared with those for the U.S. presented in Tables 1 to 3 .

There are several differences in the relative earnings position of immigrants in Australia compared to the U.S. labor market. First, immigrants in Australia from Englishspeaking countries have an advantage in mean hourly earnings of 3 percentage points compared to the native born. This compares with a 1 percentage points advantage in mean hourly earnings in the U.S. Among immigrants from non-English-speaking countries, there is a 6 percentage point disadvantage in mean hourly earnings in Australia, and a 20 percentage point disadvantage in the U.S. In terms of the hourly wage rate, immigrants appear to do relatively well in Australia compared to in the U.S. (see also Antecol et al. (2003)).

Figure 7 illustrates the payoffs to schooling in the Australian labor market. The general pattern in the payoff to schooling across the earnings distribution for Australia

${ }^{19}$ As the unit record file released from the 2001 Census on CD-ROM contains limited information on duration of residence, this variable has not been included in the estimating equation for Australia. Past research, however, has shown that duration of residence has a very small effect on the earnings of immigrants in Australia, suggesting the omission should not matter.

20 The weekly income categories are: zero; \$1-\$39; \$40-\$79; \$80-\$119; \$120-\$159; \$160-\$199; \$200-\$299; \$300-\$399; \$400-\$499; \$500-\$599; \$600-\$699; \$700-\$799; \$800-\$999; \$1000-\$1499; \$1500 or more. The hours worked categories are: 1-15; $16-24$; 25-34; 35-39; 40; 41-48; 49 or more. 
mirrors that for the U.S. Hence, the payoff to schooling for each birthplace group tends to rise as higher deciles of the earnings distribution are considered. However, the improvements in the payoff with decile of the earnings distribution in Australia vary across birthplace groups, and this variation differs from that in the U.S.

For the Australian born, there is a change of 2.5 percentage points from the lowest to the highest payoffs, and this is one percentage point less than the respective change for the native born in the U.S., of 3.6 percentage points. Among the foreign born from ENG in Australia, the increase in the payoff to schooling across the earnings distribution is 3.2 percentage points, and this is slightly more than the change (of 2.5 percentage points) for this birthplace group in the U.S. Moreover, for the foreign born from NENG in Australia, the change in the payoff to schooling across the earnings distribution is relatively greater- 4.3 percentage points. In the U.S. the payoff to schooling for the foreign born from NENG increases by 3.2 percentage points from the lowest to the highest deciles.

The better educated from NENG in Australia fare relatively well in terms of rewards for their education, unlike the situation in the U.S. where the highest payoff to schooling for the foreign born from NENG is less than even the lowest payoff for the native born. In particular, the payoffs to schooling received by the top one-half of their earnings distribution are comparable to the payoffs to schooling received by the native born in the bottom one-third of their earnings distribution. One interpretation of these findings is that they are a consequence of the greater emphasis on the recognition of skills acquired abroad in Australian immigration and settlement programs, in particular, the greater role that skills play in the allocation of visas.

Figure 8 illustrates the payoffs to labor market experience in Australia. These payoffs are quite minor across the bottom one-third of the earnings distribution, irrespective of nativity. Moreover, among the foreign born from NENG, labor market experience is generally not a significant determinant of earnings across the earnings distribution. While labor market experience was a significant determinant of earnings for the foreign born from NENG in the U.S., its partial effect was very minor across most of the earnings distribution. This aspect of the earnings determination process in the two countries appears, therefore, to be quantitatively the same. The smaller impact of experience on hourly wages in the Australian labor market may well be due to the greater 
role played by minimum wages (administered wage awards) across the occupational distribution.

The implications of these differences in payoffs for the birthplace groups on their relative earnings are summarised in Figure 9. This figure displays the results of earnings decompositions, both at the conditional mean, and across the earnings distribution.

Compared to the native born, there is evidence of a relatively larger advantage in hourly earnings among the low-skilled immigrants from English-speaking countries. There is also even a standardized earnings advantage for immigrants from non-Englishspeaking countries at the $1^{\text {st }}$ and $2^{\text {nd }}$ deciles of the earnings distribution. However, the main feature of the study for Australia is that the standardized earnings difference for immigrants from English-speaking countries is reasonably uniform across the earnings distribution, indicating a modest earnings advantage. Among immigrants from nonEnglish-speaking countries, there is evidence of a standardized earnings disadvantage beyond the second decile, and while this widens across the upper-middle segment of the earnings distribution (up to the $7^{\text {th }}$ decile) the change in this instance is not great, and a description of a reasonably constant earnings disadvantage beyond the second decile would be apt.

There are thus three main differences between these findings and those for the U.S. presented in Figure 5. First, immigrants in the bottom decile of the hourly earnings distribution do particularly well in Australia compared to the U.S. This is presumably a consequence of the greater impact of minimum and award wages in Australia. Second, immigrants in Australia from NENG, and those from ENG in the bottom four deciles of the hourly earnings distribution, fare relatively better than their counterparts in the U.S. Third, high wage immigrants from ENG in the U.S. are able to establish a considerable earnings advantage over their native born counterparts, but this is not a feature of the Australian labor market.

Hence institutions apparently matter to labor market outcomes for immigrants. There are greater relative disadvantages experienced by the less skilled in the U.S., but also the more skilled immigrants in the U.S. do relatively well. The greater rigidity of the 
Australian labor market appears to offer the least-skilled immigrants a degree of wage protection, but would appear to restrict the upward earnings mobility of immigrants. ${ }^{21}$

\section{CONCLUSION}

The empirical analyses reported in this paper show that, in the U.S. labor market, when other factors are held constant, immigrants from English-speaking countries have mean hourly earnings around 12 percent greater than the native born. In comparison, immigrants from non-English-speaking countries have mean hourly earnings around 12 percent less than that of native-born workers. However, the application of quantile regressions indicates that the relative earnings positions of both birthplace groups vary across the earnings distribution.

The earnings disadvantage of immigrants from non-English-speaking countries is slightly less at the lower deciles of the earnings distribution than it is across the middle of the earnings distribution. This was attributed to minimum wage effects. Beyond the $6^{\text {th }}$ decile of the earnings distribution, the earnings disadvantage obtained using a quantile regression approach was only about one-half of the 12 percent estimate obtained with the conventional focus on the conditional mean.

The variation in earnings disadvantage of immigrants from English-speaking countries across the first three deciles of the earnings distribution is only modest. Beyond the third decile of the earnings distribution, however, this birthplace group is depicted as having an earnings advantage over the native born that rises with higher deciles.

Comparative analyses of immigrant wage outcomes in Australia, a labor market characterized by a far greater degree of institutional wage setting, were undertaken. The economy-wide institutional wage setting in Australia was expected to affect more of the wage distribution than just the low wage earners that might be impacted by minimum wages in the U.S. All immigrants in the bottom decile of the earnings distribution do particularly well in Australia compared to the U.S., but high wage immigrants from

${ }^{21}$ Miller and Neo (2003) make the same point based on a comparison of the mean earnings of immigrants and the native born in the U.S. and Australia using earlier census data (1991 for Australia, 1990 for the U.S.). 
English-speaking countries do not do as well in Australia as in the U.S. The greater rigidity of the Australian labor market appears to offer the least-skilled immigrants a degree of wage protection, and also appears to flatten earnings-experience profiles and to impede the upward earnings mobility of more skilled immigrants.

In the U.S., relative to the native born the labor market outcomes of high-skilled immigrants are superior to those of low-skilled immigrants. This has implications for immigrant policy, favoring the allocation of visas on the basis of skill if favorable relative labor market outcomes are a goal. Similarly, the minimal variation in the relative wage outcomes of immigrants in the upper two-thirds of the wage distribution in Australia has implications for the Australian wage setting policy. These policies appear to hinder the post-immigration skill formation and labor market adjustments of immigrants. The quantile regression methodology employed in this paper allows these intricacies of labor market outcomes to be clearly established, yet they would not be revealed in analyses limited to the study of the conditional mean (OLS). 


\section{REFERENCES}

Albrecht, James, Anders Björklund, and Susan Vroman (2003). 'Is There a Glass Ceiling in Sweden?’ Journal of Labor Economics, Vol. 21, No. 1, pp.145-177.

Antecol, Heather, Deborah A. Cobb-Clark, and Stephen Trejo (2003). 'Immigration Policy and the Skills of Immigrants to Australia, Canada and the United States', Journal of Human Resources, Vol. 38, No. 1, pp. 192-218.

Antecol, Heather, Peter Kuhn and Stephen Trejo (2005). 'Assimilation via Prices or Quantities? Sources of Immigrant Earnings Growth in Australia, Canada and the United States”, photocopied, Department of Economics, Claremont Mckenna College, Claremont, California.

Australian Bureau of Statistics (2003). Technical Paper: Census of Population and Housing Household Sample File Australia 2001, Catalogue No. 2037.0, Australian Bureau of Statistics, Canberra.

Bassett, Gilbert, Mo-Tin Tam and Keith Knight (2002). 'Quantile Models and Estimators for Data Analysis', Metrika, Vol. 55, No. 1, pp. 17-26.

Bedard, Kelly (2003). 'School Quality and the Distribution of Male Earnings in Canada', Economics of Education Review, Vol. 22, No. 4, pp. 395-407.

Blinder, Alan (1973). 'Wage Discrimination: Reduced Form and Structural Estimates', Journal of Human Resources, Vol. 8, pp. 436-455.

Buchinsky, Moshe (1998). 'The Dynamics of Changes in the Female Wage Distribution in the U.S.A: A Quantile Regression Approach', Journal of Applied Econometrics, Vol. 13, No. 1, pp. 1-30.

Butcher, Kristen F. and John DiNardo (2002). 'The Immigrant and Native Born Wage Distributions: Evidence from United States Censuses', Industrial and Labor Relations Review, Vol. 56, No. 1, pp. 97-121.

Chiswick, Barry R. (1978). 'The Effect of Americanization on the Earnings of Foreignborn Men', Journal of Political Economy, Vol. 86, No. 5, pp. 897-921.

Cortes, Kalena E. (2004). 'Are Refugees Different from Economic Immigrants? Some Empirical Evidence on the Heterogeneity of Immigrant Groups in the United States', Review of Economics and Statistics, Vol. 86, No. 2, pp. 465-480.

Daneshvary, Nasser (1993). 'Earnings Differentials Between Natives and Immigrants with College Degree', American Economist, Vol. 37, No. 2, pp. 46-52. 
Drolet, Marie (2002). 'The Male-Female Wage Gap’, Perspectives, Spring, Statistics Canada, Catalogue No. 75-001-XPE.

Duleep, Harriet O. and Mark C. Regets (1996). 'The Elusive Concept of Immigrant Quality: Evidence from 1970-1990’, Discussion Paper PRIP-UI-41, Program for Research on Immigration Policy, Urban Institute, Washington, DC.

Duleep, Harriet O. and Mark C. Regets (1997). 'Measuring Immigrant Wage Growth Using Matched CPS Files', Demography, Vol. 34, No. 2, pp. 239-249.

Eide, Eric R. and Mark H. Showalter (1998). 'The Effect of School Quality on Student Performance: A Quantile Regression Approach’, Economics Letters, Vol. 58, No. 3, pp. 345-350.

Eide, Eric R., Mark H. Showalter and David Sims (2002). 'The Effects of Secondary School Quality on the Distribution of Earnings', Contemporary Economic Policy, Vol. 20, No. 2, pp. 160-171.

Garcia, Jaime, Pedro J. Hernandez and Angel Lopez-Nicolas (2001). 'How Wide is the Gap? An Investigation of Gender Wage Differences Using Quantile Regression', Empirical Economics, Vol. 26, No. 1, pp. 149-167.

Le, Anh T. and Paul W. Miller (2004). 'Inter-Temporal Decompositions of Labour Market and Social Outcomes,’ Australian Economic Papers, 43(1), pp. 10-20.

Machado, Jose A., and Jose Mata (2005). 'Counterfactual Decomposition of Changes in Wage Distributions Using Quantile Regression', Journal of Applied Econometrics, Vol. 20, No. 4, pp. 445-465.

Martins, Pedro S. and Pedro T. Pereira (2004). 'Does Education Reduce Wage Inequality? Quantile Regression Evidence from 16 Countries', Labour Economics, Vol. 11, No. 3, pp. 355-371.

Miller, Paul W. and Leanne Neo (2003). 'Labour Market Flexibility and Immigrant Adjustment', Economic Record, Vol. 79, No. 246, pp. 336-356.

Montenegro, Claudio (2001). 'Wage Distribution in Chile: Does Gender Matter? A Quantile Regression Approach', Policy Research Report on Gender and Development, Working Paper Series No. 20, The World Bank Development Research Group, The World Bank, Washington.

Mueller, Richard E. (1998). 'Public-Private Sector Wage Differentials in Canada: Evidence from Quantile Regressions', Economics Letters, Vol. 60, No. 2, pp. 229235. 
Nielsen, Helena. and Michael Rosholm (2001). 'The Public-Private Sector Wage Gap in Zambia in the 1990s: A Quantile Regression Approach', Empirical Economics, Vol. 26, No. 1, pp. 169-182.

Oaxaca, Ronald L. (1973). 'Male-Female Wage Differentials in Urban Labor Markets', International Economic Review, Vol. 14, No. 3, pp. 693-709.

Sakellariou, Chris (2004). 'Gender Earnings Differentials Using Quantile Regressions', Journal of Labor Research, Vol. 25, No. 3, pp. 457-468.

Yuengert, Andrew M. (1994). 'Immigrant Earnings, Relative to What? The Importance of Earnings Function Specification and Comparison Points', Journal of Applied Econometrics, Vol. 9, pp. 71-90. 


\section{APPENDIX A \\ DESCRIPTION OF VARIABLES}

The variables used in the statistical analyses are defined below. Mnemonic names are also listed where relevant.

\section{a. 2000 U.S. Census}

Data Source: 2000 Census of Population, Public Use Microdata Sample, 1 percent sample of the population.

Definition of Population: Native born and Foreign-born men aged twenty-five to sixtyfour, who are residents of the 50 States and the District of Columbia.

\section{Dependent Variable:}

Earnings: This is the natural logarithm of the individual's hourly earnings for 1999, computed by dividing the annual income for 1999 by the product of weeks worked in 1999 and hours worked per week in 1999.

\section{Explanatory Variables:}

Educational Attainment (EDUC): This variable records the total years of full-time equivalent education. It has been constructed from the Census data on educational attainment by assigning the following values to the Census categories: completed less than fifth grade (2 years); completed fifth or sixth grade (5.5); completed seventh or eighth grade (7.5); completed ninth grade (9); completed tenth grade (10); completed 11th grade (11); completed 12th grade or high school (12); attended college for less than one year (12.5); attended college for more than one year or completed college (14); Bachelor's degree (16); Master's degree (17.5); Professional degree (18.5); Doctorate (20).

Labor Market Experience (EXP): This is a measure of potential labor market experience, computed as AGE - Years of Education - 6 .

Birthplace (ENG, NENG): The foreign born are distinguished according to whether they were born in a predominately English-speaking country (ENG) or a predominately nonEnglish-speaking country (NENG). The English-speaking countries are the UK, Ireland, Canada, Australia, New Zealand and the English-speaking islands in the Caribbean Sea.

Years Since Migration (YSM): This is computed from the year the foreign born person came to the United States to stay.

English Language Fluency: Two dichotomous variables are used to capture proficiency levels among both the native born and immigrants. These distinguish individuals who speak a language other than English in the home and who speak English either: (i) "very well" or "well"; and (ii) "not well" or "not at all". The benchmark group is those who speak only English at home. 
Race (BLACK): This is a dichotomous variable, set to one if the individual is Black, and set to zero for all other racial groups.

Marital Status (MARRIED): This is a dichotomous variable that distinguishes individuals who are married, spouse present (equal to 1) from all other marital states.

Location: The two location variables record residence of a non-metropolitan area (NONMET) or of the Southern States (SOUTH). The states included in the latter are: Alabama, Arkansas, Delaware, District of Columbia, Florida, Georgia, Kentucky, Louisiana, Maryland, Mississippi, Missouri, North Carolina, Oklahoma, South Carolina, Tennessee, Texas, Virginia, West Virginia.

Means and standard deviations for these variables are reported in Table A.1.

\section{b. 2001 Australian Census}

Data Source: 2001 Australian Census of Population and Housing, 1 percent sample.

Definition of Population: Native born and foreign born males aged 25-64 years.

\section{Dependent Variable:}

Earnings: This is the natural logarithm of hourly earnings (where earnings are defined as gross earnings from all sources). As weekly income was coded in intervals, midpoints of intervals were used to construct a continuous measure. The open-ended upper category was assigned a value of 1.5 times the lower threshold level. Weekly hours were recorded in intervals so midpoints were used to construct a continuous measure. Hourly earnings were then constructed by dividing weekly income by weekly hours worked.

\section{Explanatory Variables:}

Educational Attainment (EDUC): This is a continuous variable that records the equivalent years of full-time education completed by the individual. Individuals holding a Postgraduate degree are assigned 19 years of education, Graduate Diploma and Graduate Certificate holders are assumed to have 17 years, Bachelor degree holders have the equivalent of 15.5 years of education, Advanced Diploma and Diploma holders are coded as having 14 years, holders of Certificate are assigned 13 years, those who have completed Year 12 are coded as having 12 years of education, those who completed Year 11 as 11 years of education, and those who completed Year 10 or below are coded as having 10 years of education.

Labor Market Experience (EXP): This is a measure of potential labor market experience, computed as AGE - Years of Education - 5.

Birthplace (ENG, NENG): The foreign born are distinguished according to whether they were born in a predominately English-speaking country (ENG) or a predominately non- 
English-speaking country (NENG). The English-speaking countries are the UK, Ireland, New Zealand and North America.

Marital Status (MARRIED): Dichotomous variable set to one if an individual is married and set to zero otherwise.

English Language Fluency: Two dichotomous variables are used to capture proficiency levels among both the native born and immigrants. These distinguish individuals who speak a language other than English in the home and who speak English either: (i) "very well" or "well"; and (ii) "not well" or "not at all”. The benchmark group is those who speak only English at home. 
Table 1

OLS and Quantile Regression Estimates, Adult Native Born Males, 2000 U.S. Census

\begin{tabular}{|c|c|c|c|c|c|c|c|c|c|c|}
\hline \multirow[t]{2}{*}{ Variable } & \multirow[t]{2}{*}{ OLS } & \multicolumn{9}{|c|}{ Quantile } \\
\hline & & 0.1 & 0.2 & 0.3 & 0.4 & 0.5 & 0.6 & 0.7 & 0.8 & 0.9 \\
\hline Constant & $\begin{array}{c}0.801 \\
(88.83)\end{array}$ & $\begin{array}{c}0.376 \\
(21.33)\end{array}$ & $\begin{array}{c}0.515 \\
(43.33)\end{array}$ & $\begin{array}{c}0.625 \\
(60.65)\end{array}$ & $\begin{array}{c}0.716 \\
(75.27)\end{array}$ & $\begin{array}{c}0.796 \\
(94.03)\end{array}$ & $\begin{array}{c}0.876 \\
(111.79)\end{array}$ & $\begin{array}{c}0.965 \\
(124.04)\end{array}$ & $\begin{array}{c}1.077 \\
(110.18)\end{array}$ & $\begin{array}{c}1.184 \\
(76.08)\end{array}$ \\
\hline $\begin{array}{l}\text { Educational } \\
\text { Attainment }\end{array}$ & $\begin{array}{c}0.099 \\
(230.62)\end{array}$ & $\begin{array}{c}0.082 \\
(93.96)\end{array}$ & $\begin{array}{c}0.090 \\
(141.43)\end{array}$ & $\begin{array}{c}0.094 \\
(168.03)\end{array}$ & $\begin{array}{c}0.098 \\
(191.30)\end{array}$ & $\begin{array}{c}0.100 \\
(206.52)\end{array}$ & $\begin{array}{c}0.103 \\
(237.04)\end{array}$ & $\begin{array}{c}0.105 \\
(229.54)\end{array}$ & $\begin{array}{c}0.109 \\
(213.05)\end{array}$ & $\begin{array}{c}0.118 \\
(144.43)\end{array}$ \\
\hline Experience & $\begin{array}{c}0.026 \\
(62.21)\end{array}$ & $\begin{array}{c}0.024 \\
(37.63)\end{array}$ & $\begin{array}{c}0.027 \\
(47.40)\end{array}$ & $\begin{array}{c}0.028 \\
(54.88)\end{array}$ & $\begin{array}{c}0.029 \\
(70.56)\end{array}$ & $\begin{array}{c}0.029 \\
(76.05)\end{array}$ & $\begin{array}{c}0.030 \\
(82.88)\end{array}$ & $\begin{array}{c}0.030 \\
(64.46)\end{array}$ & $\begin{array}{c}0.029 \\
(57.43)\end{array}$ & $\begin{array}{c}0.029 \\
(34.33)\end{array}$ \\
\hline Experience & -0.375 & -0.503 & -0.472 & -0.452 & -0.430 & -0.409 & -0.392 & -0.365 & -0.329 & -0.246 \\
\hline Squared/1000 & (43.69) & $(24.40)$ & $(38.20)$ & $(41.20)$ & (48.33) & $(48.97)$ & $(49.59)$ & $(40.00)$ & (31.88) & $(14.53)$ \\
\hline Married & $\begin{array}{c}0.205 \\
(91.04)\end{array}$ & $\begin{array}{c}0.289 \\
(71.13)\end{array}$ & $\begin{array}{c}0.253 \\
(91.65)\end{array}$ & $\begin{array}{c}0.230 \\
(87.57)\end{array}$ & $\begin{array}{c}0.207 \\
(91.17)\end{array}$ & $\begin{array}{c}0.192 \\
(88.50)\end{array}$ & $\begin{array}{c}0.178 \\
(91.86)\end{array}$ & $\begin{array}{c}0.165 \\
(74.21)\end{array}$ & $\begin{array}{c}0.154 \\
(60.78)\end{array}$ & $\begin{array}{c}0.147 \\
(31.95)\end{array}$ \\
\hline Black & $\begin{array}{c}-0.098 \\
(28.22)\end{array}$ & $\begin{array}{l}-0.138 \\
(22.08)\end{array}$ & $\begin{array}{l}-0.131 \\
(25.62)\end{array}$ & $\begin{array}{l}-0.123 \\
(29.64)\end{array}$ & $\begin{array}{l}-0.117 \\
(31.68)\end{array}$ & $\begin{array}{l}-0.112 \\
(33.57)\end{array}$ & $\begin{array}{l}-0.108 \\
(31.89)\end{array}$ & $\begin{array}{c}-0.101 \\
(25.57)\end{array}$ & $\begin{array}{c}-0.093 \\
(19.60)\end{array}$ & $\begin{array}{c}-0.086 \\
(11.57)\end{array}$ \\
\hline Metropolitan & $\begin{array}{c}0.210 \\
(39.90)\end{array}$ & $\begin{array}{c}0.207 \\
(21.80)\end{array}$ & $\begin{array}{c}0.193 \\
(28.94)\end{array}$ & $\begin{array}{c}0.186 \\
(31.61)\end{array}$ & $\begin{array}{c}0.183 \\
(34.20)\end{array}$ & $\begin{array}{c}0.188 \\
(35.95)\end{array}$ & $\begin{array}{c}0.184 \\
(36.74)\end{array}$ & $\begin{array}{c}0.184 \\
(40.75)\end{array}$ & $\begin{array}{c}0.182 \\
(30.52)\end{array}$ & $\begin{array}{c}0.188 \\
(21.20)\end{array}$ \\
\hline South & $\begin{array}{c}-0.076 \\
(34.85)\end{array}$ & $\begin{array}{c}-0.074 \\
(19.95)\end{array}$ & $\begin{array}{c}-0.084 \\
(28.88)\end{array}$ & $\begin{array}{l}-0.092 \\
(39.85)\end{array}$ & $\begin{array}{l}-0.095 \\
(44.15)\end{array}$ & $\begin{array}{l}-0.092 \\
(43.26)\end{array}$ & $\begin{array}{l}-0.085 \\
(42.13)\end{array}$ & $\begin{array}{l}-0.080 \\
(34.38)\end{array}$ & $\begin{array}{l}-0.073 \\
(27.36)\end{array}$ & $\begin{array}{c}-0.072 \\
(17.62)\end{array}$ \\
\hline Speaks English & -0.047 & -0.097 & -0.093 & -0.077 & -0.071 & -0.062 & -0.041 & -0.034 & -0.013 & 0.019 \\
\hline Very Well/Well & $(10.54)$ & $(12.90)$ & $(16.88)$ & (15.99) & $(17.20)$ & (13.79) & $(10.68)$ & $(8.44)$ & $(2.68)$ & $(2.21)$ \\
\hline Speaks English Not & 0.013 & -0.090 & -0.066 & -0.036 & -0.012 & -0.010 & 0.005 & 0.029 & 0.047 & 0.133 \\
\hline Well/ Not at All & $(0.75)$ & $(2.73)$ & $(2.06)$ & $(1.83)$ & $(0.68)$ & $(0.69)$ & $(0.28)$ & $(1.44)$ & $(1.96)$ & $(2.67)$ \\
\hline
\end{tabular}

Source: 2000 U.S. Census, Public Use Microdata Sample (1\% Sample): Sample size is 533,306. 
Table 2

OLS and Quantile Regression Estimates, Adult Foreign Born Males from English-speaking Countries, 2000 U.S. Census

\begin{tabular}{|c|c|c|c|c|c|c|c|c|c|c|}
\hline \multirow[t]{2}{*}{ Variable } & \multirow[t]{2}{*}{$O L S$} & \multicolumn{9}{|c|}{ Quantile } \\
\hline & & 0.1 & 0.2 & 0.3 & 0.4 & 0.5 & 0.6 & 0.7 & 0.8 & 0.9 \\
\hline \multirow[t]{2}{*}{ Constant } & 1.451 & 0.637 & 0.897 & 1.150 & 1.233 & 1.329 & 1.540 & 1.737 & 2.063 & 2.288 \\
\hline & (13.46) & $(2.75)$ & $(6.50)$ & $(9.02)$ & (12.03) & $(12.76)$ & (13.62) & (11.33) & (12.11) & (8.26) \\
\hline Educational & 0.072 & 0.068 & 0.072 & 0.075 & 0.078 & 0.079 & 0.077 & 0.077 & 0.078 & 0.093 \\
\hline Attainment & (25.18) & (10.82) & (16.82) & (18.42) & (22.24) & (22.63) & (28.59) & (23.61) & (21.02) & (19.01) \\
\hline \multirow[t]{2}{*}{ Experience } & 0.022 & 0.015 & 0.019 & 0.021 & 0.021 & 0.022 & 0.023 & 0.025 & 0.024 & 0.027 \\
\hline & (6.83) & $(2.71)$ & $(4.22)$ & $(5.24)$ & (6.98) & (6.55) & (7.14) & $(7.21)$ & $(5.75)$ & (3.81) \\
\hline Experience & -0.289 & -0.281 & -0.345 & -0.303 & -0.278 & -0.269 & -0.260 & -0.282 & -0.219 & -0.145 \\
\hline Squared/1000 & (4.63) & $(2.50)$ & (3.58) & (3.91) & $(4.97)$ & $(4.08)$ & $(4.09)$ & (3.96) & (2.63) & (0.99) \\
\hline \multirow[t]{2}{*}{ Married } & 0.159 & 0.213 & 0.186 & 0.164 & 0.158 & 0.161 & 0.132 & 0.110 & 0.123 & 0.125 \\
\hline & $(9.21)$ & (7.37) & (8.21) & (8.30) & (9.16) & (9.03) & (6.97) & (5.64) & (5.99) & (3.63) \\
\hline \multirow[t]{2}{*}{ Black } & -0.181 & -0.034 & -0.095 & -0.125 & -0.146 & -0.156 & -0.180 & -0.234 & -0.269 & -0.325 \\
\hline & $(10.08)$ & $(1.07)$ & (3.99) & $(6.46)$ & (8.63) & $(9.42)$ & $(10.85)$ & $(11.86)$ & $(11.53)$ & (9.38) \\
\hline \multirow[t]{2}{*}{ Metropolitan } & 0.216 & 0.183 & 0.197 & 0.125 & 0.179 & 0.234 & 0.190 & 0.165 & 0.034 & -0.094 \\
\hline & (2.33) & $(0.85)$ & (1.64) & $(1.21)$ & $(2.22)$ & $(2.73)$ & (1.98) & $(1.14)$ & $(0.23)$ & $(0.39)$ \\
\hline \multirow[t]{2}{*}{ South } & -0.071 & -0.047 & -0.070 & -0.079 & -0.092 & -0.108 & -0.104 & -0.074 & -0.066 & -0.079 \\
\hline & $(3.90)$ & $(1.35)$ & (2.93) & $(3.72)$ & $(5.50)$ & (6.19) & $(5.97)$ & (3.81) & $(2.70)$ & $(2.02)$ \\
\hline Speaks English & -0.214 & -0.222 & -0.227 & -0.235 & -0.243 & -0.235 & -0.222 & -0.210 & -0.183 & -0.164 \\
\hline Very Well/Well & $(11.40)$ & (5.89) & $(8.88)$ & $(10.25)$ & $(10.91)$ & $(11.76)$ & $(11.24)$ & (8.54) & $(7.54)$ & $(4.56)$ \\
\hline Speaks English Not & -0.377 & -0.262 & -0.365 & -0.406 & -0.417 & -0.421 & -0.391 & -0.380 & -0.345 & -0.327 \\
\hline Well/ Not at All & $(12.22)$ & $(6.63)$ & $(11.22)$ & (13.69) & (11.99) & $(11.12)$ & (10.36) & $(10.29)$ & $(6.26)$ & (4.23) \\
\hline Years Since & -0.003 & 0.007 & 0.005 & 0.002 & -0.001 & -0.004 & -0.005 & -0.006 & -0.010 & -0.013 \\
\hline Migration (YSM) & $(1.46)$ & $(1.75)$ & (1.56) & $(0.53)$ & $(0.26)$ & $(1.44)$ & $(2.04)$ & $(2.21)$ & $(3.27)$ & $(2.02)$ \\
\hline \multirow[t]{2}{*}{ YSM Squared/1000 } & 0.054 & -0.112 & -0.061 & -0.013 & 0.027 & 0.067 & 0.090 & 0.123 & 0.167 & 0.191 \\
\hline & (1.12) & $(1.29)$ & $(0.84)$ & $(0.21)$ & $(0.47)$ & $(1.20)$ & $(1.70)$ & $(2.04)$ & $(2.48)$ & $(1.26)$ \\
\hline
\end{tabular}

Source: 2000 U.S. Census, Public Use Microdata Sample (1\% Sample): Sample size is 9,385. 
Table 3

OLS and Quantile Regression Estimates, Adult Foreign Born Males from non-English-speaking Countries, 2000 U.S. Census

\begin{tabular}{|c|c|c|c|c|c|c|c|c|c|c|}
\hline \multirow[t]{2}{*}{ Variable } & \multirow[t]{2}{*}{ OLS } & \multicolumn{9}{|c|}{ Quantile } \\
\hline & & 0.1 & 0.2 & 0.3 & 0.4 & 0.5 & 0.6 & 0.7 & 0.8 & 0.9 \\
\hline \multirow{2}{*}{ Constant } & 1.669 & 1.171 & 1.294 & 1.409 & 1.471 & 1.610 & 1.733 & 1.850 & 1.963 & 2.190 \\
\hline & $(50.66)$ & $(24.00)$ & (29.91) & $(46.75)$ & (54.71) & (47.93) & $(62.50)$ & (54.68) & (47.79) & (29.92) \\
\hline Educational & 0.052 & 0.034 & 0.040 & 0.046 & 0.050 & 0.053 & 0.057 & 0.060 & 0.063 & 0.066 \\
\hline Attainment & (73.68) & (27.52) & $(42.70)$ & (55.98) & (61.37) & (66.77) & (82.03) & (87.55) & (72.98) & (50.35) \\
\hline \multirow[t]{2}{*}{ Experience } & 0.003 & -0.001 & 0.002 & 0.002 & 0.003 & 0.001 & 0.002 & 0.003 & 0.005 & 0.012 \\
\hline & $(2.82)$ & $(0.65)$ & (1.54) & (2.09) & (2.33) & (1.34) & (1.96) & $(2.34)$ & (3.77) & (5.31) \\
\hline Experience & 0.011 & -0.001 & -0.039 & -0.014 & 0.003 & 0.044 & 0.050 & 0.065 & 0.057 & -0.013 \\
\hline Squared/1000 & $(0.54)$ & $(0.04)$ & $(1.41)$ & $(0.67)$ & $(0.12)$ & $(2.15)$ & $(2.45)$ & $(2.90)$ & (2.19) & $(0.28)$ \\
\hline \multirow[t]{2}{*}{ Married } & 0.170 & 0.166 & 0.165 & 0.159 & 0.169 & 0.174 & 0.177 & 0.183 & 0.174 & 0.169 \\
\hline & (27.87) & (17.64) & (24.27) & (25.03) & (27.69) & (26.91) & (28.57) & (25.67) & (20.06) & (13.48) \\
\hline \multirow[t]{2}{*}{ Black } & -0.059 & 0.005 & -0.007 & -0.005 & -0.021 & -0.052 & -0.082 & -0.086 & -0.103 & -0.080 \\
\hline & (3.99) & $(0.18)$ & $(0.39)$ & $(0.28)$ & $(1.56)$ & (3.65) & $(4.81)$ & $(4.14)$ & $(4.12)$ & $(2.72)$ \\
\hline \multirow[t]{2}{*}{ Metropolitan } & 0.143 & 0.070 & 0.105 & 0.112 & 0.149 & 0.154 & 0.153 & 0.164 & 0.204 & 0.204 \\
\hline & $(5.14)$ & (1.69) & $(3.04)$ & $(5.34)$ & $(7.50)$ & $(5.45)$ & $(6.50)$ & $(5.15)$ & $(5.44)$ & (3.17) \\
\hline \multirow[t]{2}{*}{ South } & -0.086 & -0.077 & -0.071 & -0.075 & -0.080 & -0.084 & -0.087 & -0.086 & -0.090 & -0.072 \\
\hline & $(13.85)$ & $(7.76)$ & (9.30) & $(10.95)$ & (11.35) & $(11.83)$ & $(12.32)$ & $(11.76)$ & $(10.47)$ & $(5.91)$ \\
\hline Speaks English & -0.055 & -0.020 & -0.029 & -0.042 & -0.048 & -0.052 & -0.059 & -0.059 & -0.058 & -0.078 \\
\hline Very Well/Well & $(5.47)$ & $(1.24)$ & $(2.80)$ & $(3.80)$ & (4.89) & $(4.73)$ & $(5.55)$ & (5.13) & $(4.66)$ & (3.31) \\
\hline Speaks English Not & -0.224 & -0.168 & -0.190 & -0.220 & -0.225 & -0.238 & -0.252 & -0.252 & -0.239 & -0.245 \\
\hline Well/ Not at All & $(19.49)$ & (9.17) & $(16.33)$ & $(19.23)$ & $(21.78)$ & $(20.00)$ & $(21.32)$ & $(17.55)$ & $(15.97)$ & $(8.20)$ \\
\hline Years Since & 0.009 & 0.012 & 0.013 & 0.014 & 0.013 & 0.011 & 0.009 & 0.006 & 0.004 & 0.001 \\
\hline Migration (YSM) & $(10.90)$ & $(8.35)$ & $(11.49)$ & $(13.77)$ & (13.37) & $(12.20)$ & $(9.08)$ & (5.59) & (3.37) & $(0.67)$ \\
\hline \multirow[t]{2}{*}{ YSM Squared/1000 } & -0.046 & -0.080 & -0.079 & -0.099 & -0.093 & -0.062 & -0.036 & 0.006 & 0.009 & 0.041 \\
\hline & $(2.40)$ & $(2.41)$ & $(2.90)$ & (4.58) & $(4.14)$ & $(2.98)$ & (1.65) & $(0.26)$ & $(0.38)$ & $(0.93)$ \\
\hline
\end{tabular}

Source: 2000 U.S. Census, Public Use Microdata Sample (1\% Sample): Sample size is 74,809. 
Table 4

OLS and Quantile Regression Estimates, Native Born Adult Males from Australia, 2001 Australian Census

\begin{tabular}{|c|c|c|c|c|c|c|c|c|c|c|}
\hline \multirow[t]{2}{*}{ Variable } & \multirow[t]{2}{*}{ OLS } & \multicolumn{9}{|c|}{ Quantile } \\
\hline & & 0.1 & 0.2 & 0.3 & 0.4 & 0.5 & 0.6 & 0.7 & 0.8 & 0.9 \\
\hline Constant & $\begin{array}{c}1.409 \\
(43.49)\end{array}$ & $\begin{array}{c}1.187 \\
(19.35)\end{array}$ & $\begin{array}{c}1.286 \\
(32.05)\end{array}$ & $\begin{array}{c}1.190 \\
(32.64)\end{array}$ & $\begin{array}{c}1.191 \\
(26.52)\end{array}$ & $\begin{array}{c}1.256 \\
(39.45)\end{array}$ & $\begin{array}{c}1.239 \\
(48.65)\end{array}$ & $\begin{array}{c}1.223 \\
(32.03)\end{array}$ & $\begin{array}{c}1.531 \\
(34.38)\end{array}$ & $\begin{array}{c}1.984 \\
(39.50)\end{array}$ \\
\hline $\begin{array}{l}\text { Educational } \\
\text { Attainment }\end{array}$ & $\begin{array}{c}0.101 \\
(55.83)\end{array}$ & $\begin{array}{c}0.089 \\
(26.26)\end{array}$ & $\begin{array}{c}0.089 \\
(40.34)\end{array}$ & $\begin{array}{c}0.098 \\
(50.75)\end{array}$ & $\begin{array}{c}0.104 \\
(43.54)\end{array}$ & $\begin{array}{c}0.105 \\
(57.33)\end{array}$ & $\begin{array}{c}0.112 \\
(69.88)\end{array}$ & $\begin{array}{c}0.119 \\
(49.63)\end{array}$ & $\begin{array}{c}0.114 \\
(41.11)\end{array}$ & $\begin{array}{c}0.099 \\
(36.69)\end{array}$ \\
\hline Experience & $\begin{array}{c}0.020 \\
(11.40)\end{array}$ & $\begin{array}{l}0.009 \\
(2.70)\end{array}$ & $\begin{array}{l}0.016 \\
(7.20)\end{array}$ & $\begin{array}{c}0.024 \\
(11.24)\end{array}$ & $\begin{array}{c}0.025 \\
(11.53)\end{array}$ & $\begin{array}{c}0.026 \\
(17.01)\end{array}$ & $\begin{array}{c}0.028 \\
(20.86)\end{array}$ & $\begin{array}{c}0.031 \\
(14.19)\end{array}$ & $\begin{array}{l}0.024 \\
(9.21)\end{array}$ & $\begin{array}{l}0.021 \\
(8.42)\end{array}$ \\
\hline Experience & -0.034 & -0.028 & -0.031 & -0.043 & -0.043 & -0.043 & -0.045 & -0.048 & -0.032 & -0.023 \\
\hline Squared/100 & $(10.02)$ & (3.95) & $(6.79)$ & $(10.71)$ & $(10.53)$ & $(13.67)$ & $(17.27)$ & $(11.20)$ & $(6.10)$ & $(4.57)$ \\
\hline Speaks English & -0.077 & -0.152 & -0.069 & -0.067 & -0.053 & -0.043 & -0.037 & -0.039 & -0.069 & -0.061 \\
\hline Very Well/Well & $(4.29)$ & (3.67) & $(3.48)$ & $(3.54)$ & (3.14) & $(3.04)$ & (1.94) & $(2.41)$ & $(2.96)$ & (1.66) \\
\hline Speaks English Not & -0.302 & -0.500 & -0.565 & -0.399 & -0.373 & -0.381 & -0.105 & -0.059 & -0.055 & -0.004 \\
\hline Well/Not at All & $(2.47)$ & $(0.35)$ & $(2.09)$ & $(2.05)$ & $(1.84)$ & (1.64) & $(0.43)$ & $(1.96)$ & $(0.18)$ & $(0.00)$ \\
\hline Married & $\begin{array}{l}0.076 \\
(8.45)\end{array}$ & $\begin{array}{l}0.048 \\
(3.14)\end{array}$ & $\begin{array}{l}0.069 \\
(7.22)\end{array}$ & $\begin{array}{l}0.080 \\
(9.09)\end{array}$ & $\begin{array}{c}0.102 \\
(12.13)\end{array}$ & $\begin{array}{c}0.104 \\
(13.94)\end{array}$ & $\begin{array}{c}0.115 \\
(14.83)\end{array}$ & $\begin{array}{c}0.129 \\
(13.51)\end{array}$ & $\begin{array}{c}0.102 \\
(11.20)\end{array}$ & $\begin{array}{l}0.083 \\
(7.43)\end{array}$ \\
\hline
\end{tabular}

Source: 2001 Australian Census of Population and Housing Household Sample File: Sample size 21,505. 
Table 5

OLS and Quantile Regression Estimates, Adult Males from English-Speaking Countries, 2001 Australian Census

\begin{tabular}{|c|c|c|c|c|c|c|c|c|c|c|}
\hline \multirow[t]{2}{*}{ Variable } & \multirow[t]{2}{*}{$O L S$} & \multicolumn{9}{|c|}{ Quantile } \\
\hline & & 0.1 & 0.2 & 0.3 & 0.4 & 0.5 & 0.6 & 0.7 & 0.8 & 0.9 \\
\hline Constant & $\begin{array}{c}1.774 \\
(21.20)\end{array}$ & $\begin{array}{c}1.553 \\
(13.25)\end{array}$ & $\begin{array}{c}1.632 \\
(23.75)\end{array}$ & $\begin{array}{c}1.494 \\
(19.28)\end{array}$ & $\begin{array}{c}1.420 \\
(14.96)\end{array}$ & $\begin{array}{c}1.391 \\
(25.12)\end{array}$ & $\begin{array}{c}1.565 \\
(18.54)\end{array}$ & $\begin{array}{c}1.538 \\
(14.26)\end{array}$ & $\begin{array}{c}1.971 \\
(14.89)\end{array}$ & $\begin{array}{c}2.449 \\
(11.44)\end{array}$ \\
\hline Educational & 0.086 & 0.066 & 0.073 & 0.086 & 0.095 & 0.100 & 0.098 & 0.103 & 0.098 & 0.083 \\
\hline Attainment & (20.31) & (8.33) & $(19.52)$ & (17.83) & $(17.14)$ & $(42.07)$ & $(21.02)$ & $(18.41)$ & $(17.45)$ & (7.71) \\
\hline \multirow[t]{2}{*}{ Experience } & 0.012 & 0.006 & 0.005 & 0.012 & 0.018 & 0.024 & 0.019 & 0.025 & 0.013 & 0.020 \\
\hline & $(2.67)$ & $(0.75)$ & (1.44) & (3.03) & (4.69) & $(6.60)$ & (3.60) & $(4.45)$ & (1.52) & $(2.28)$ \\
\hline Experience & -0.022 & -0.017 & -0.010 & -0.022 & -0.031 & -0.042 & -0.030 & -0.041 & -0.018 & -0.035 \\
\hline Squared/100 & $(2.61)$ & $(1.03)$ & (1.48) & (2.69) & $(4.43)$ & (6.59) & $(2.83)$ & $(4.04)$ & (1.16) & (2.18) \\
\hline Speaks English & -0.048 & 0.061 & -0.030 & -0.065 & -0.089 & -0.068 & -0.088 & -0.096 & -0.056 & 0.000 \\
\hline Very Well/Well & (1.08) & $(0.94)$ & $(0.89)$ & $(1.80)$ & (1.83) & (1.63) & (1.99) & (1.23) & $(0.76)$ & $(0.00)$ \\
\hline Speaks English Not & -0.053 & 0.010 & -0.125 & -0.078 & -0.183 & -0.151 & -0.181 & -0.173 & 0.092 & 0.240 \\
\hline Well/Not at All & $(0.42)$ & $(0.01)$ & $(0.98)$ & $(0.59)$ & (1.69) & (1.34) & (1.14) & $(0.73)$ & $(0.24)$ & $(0.22)$ \\
\hline \multirow[t]{2}{*}{ Married } & 0.070 & 0.044 & 0.067 & 0.106 & 0.116 & 0.111 & 0.111 & 0.157 & 0.076 & 0.007 \\
\hline & $(3.12)$ & (1.43) & $(3.58)$ & $(6.83)$ & $(5.05)$ & $(5.50)$ & (4.51) & (4.89) & $(2.44)$ & $(0.14)$ \\
\hline
\end{tabular}

Source: 2001 Australian Census of Population and Housing Household Sample File: Sample size 3,623. 
Table 6

OLS and Quantile Regression Estimates, Native Born Adult Males from Non-English-Speaking Countries, 2001 Australian

\begin{tabular}{|c|c|c|c|c|c|c|c|c|c|c|}
\hline \multirow{3}{*}{ Variable } & \multirow{3}{*}{ OLS } & & & & & & & & & \\
\hline & & \multicolumn{9}{|c|}{ Quantile } \\
\hline & & 0.1 & 0.2 & 0.3 & 0.4 & 0.5 & 0.6 & 0.7 & 0.8 & 0.9 \\
\hline \multirow[t]{2}{*}{ Constant } & 1.881 & 1.705 & 1.625 & 1.619 & 1.704 & 1.715 & 1.784 & 1.739 & 1.927 & 2.590 \\
\hline & $(24.78)$ & (12.52) & (21.66) & (23.01) & (24.79) & (26.28) & (27.11) & (22.74) & (15.76) & (20.11) \\
\hline Educational & 0.081 & 0.054 & 0.073 & 0.080 & 0.084 & 0.091 & 0.092 & 0.095 & 0.097 & 0.082 \\
\hline Attainment & (21.53) & (6.80) & (18.63) & $(21.25)$ & (24.49) & $(24.52)$ & (27.59) & (21.95) & (18.01) & (15.06) \\
\hline \multirow[t]{2}{*}{ Experience } & 0.003 & 0.004 & 0.005 & 0.006 & 0.003 & 0.002 & 0.006 & 0.013 & 0.011 & -0.003 \\
\hline & (0.89) & (0.69) & $(1.46)$ & (1.84) & $(0.97)$ & $(0.49)$ & (1.84) & (2.75) & (1.61) & $(0.51)$ \\
\hline Experience & -0.001 & -0.005 & -0.005 & -0.005 & -0.001 & 0.002 & -0.004 & -0.014 & -0.011 & 0.016 \\
\hline Squared/100 & $(0.08)$ & $(0.47)$ & (0.68) & $(0.75)$ & $(0.12)$ & $(0.41)$ & $(0.62)$ & (1.64) & $(0.93)$ & (1.27) \\
\hline Speaks English & -0.156 & -0.145 & -0.158 & -0.155 & -0.154 & -0.133 & -0.153 & 0.132 & -0.149 & -0.176 \\
\hline Very Well/Well & $(8.26)$ & $(4.73)$ & $(8.13)$ & $(8.64)$ & (10.38) & $(8.36)$ & $(8.49)$ & (5.99) & $(5.73)$ & $(5.87)$ \\
\hline Speaks English Not & -0.278 & -0.171 & -0.290 & -0.286 & -0.284 & -0.289 & -0.307 & -0.319 & -0.280 & -0.351 \\
\hline Well/Not at All & (8.16) & $(3.74)$ & (11.20) & $(10.40)$ & $(10.28)$ & (11.99) & $(8.63)$ & $(7.35)$ & $(5.42)$ & $(4.45)$ \\
\hline \multirow[t]{2}{*}{ Married } & 0.051 & -0.054 & 0.006 & 0.042 & 0.063 & 0.080 & 0.055 & 0.103 & 0.089 & 0.069 \\
\hline & $(2.31)$ & $(1.80)$ & $(0.30)$ & $(2.21)$ & $(3.62)$ & $(3.76)$ & $(2.57)$ & $(4.23)$ & $(2.74)$ & $(1.55)$ \\
\hline
\end{tabular}

Source: 2001 Australian Census of Population and Housing Household Sample File: Sample size 4,570. 
Figure 1

Distribution of Log Hourly Earnings, Employed Workers 25-64 Years in the U.S., by Nativity, 1999

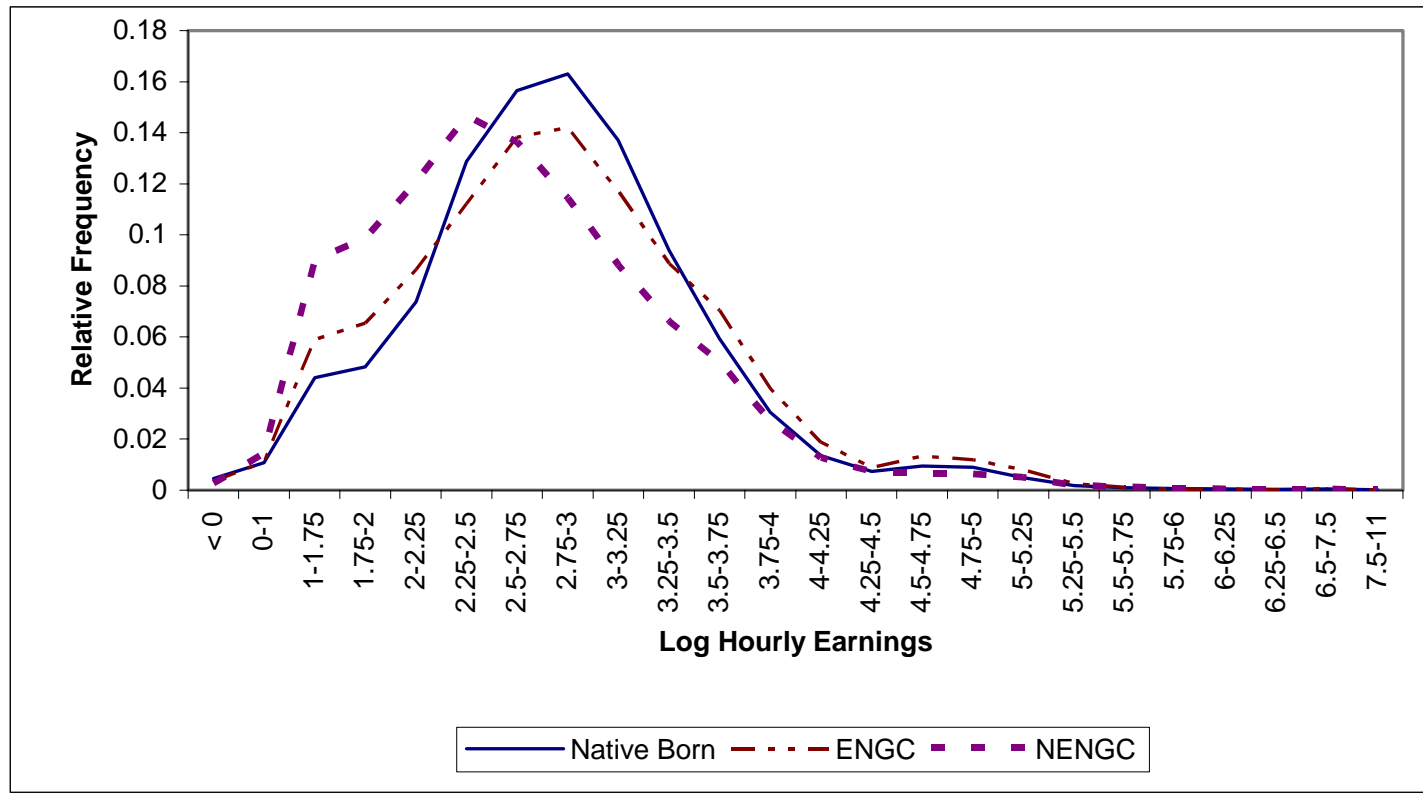

rce: 2000 U.S. Census, 1\% PUMS.

Figure 2

Simple Comparisons of Earnings of Native Born and Foreign Born Males Aged 2564 Years in the U.S., by Decile of the Earnings Distribution, 1999

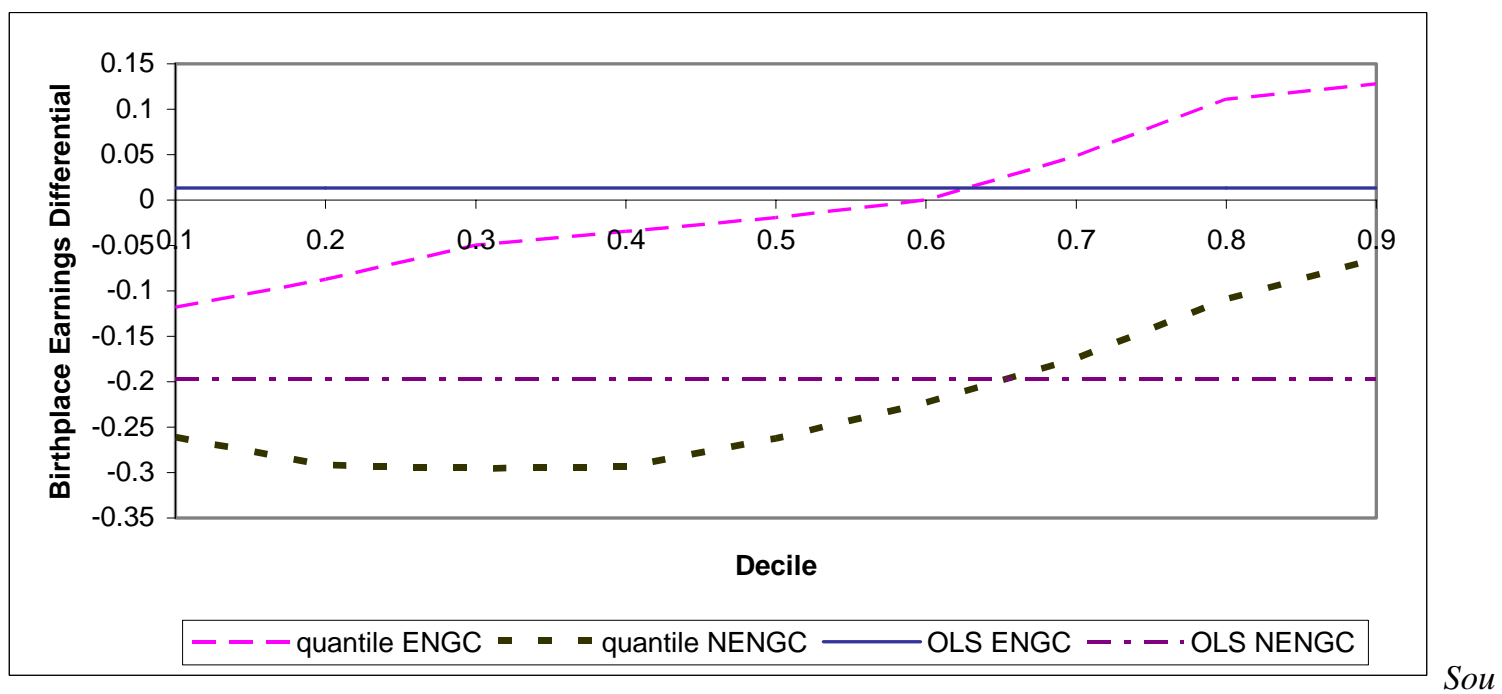

rce: 2000 U.S. Census 1\% PUMS. 
Figure 3

Payoffs to Education by Decile, Adult Males in the U.S., by Nativity, 1999

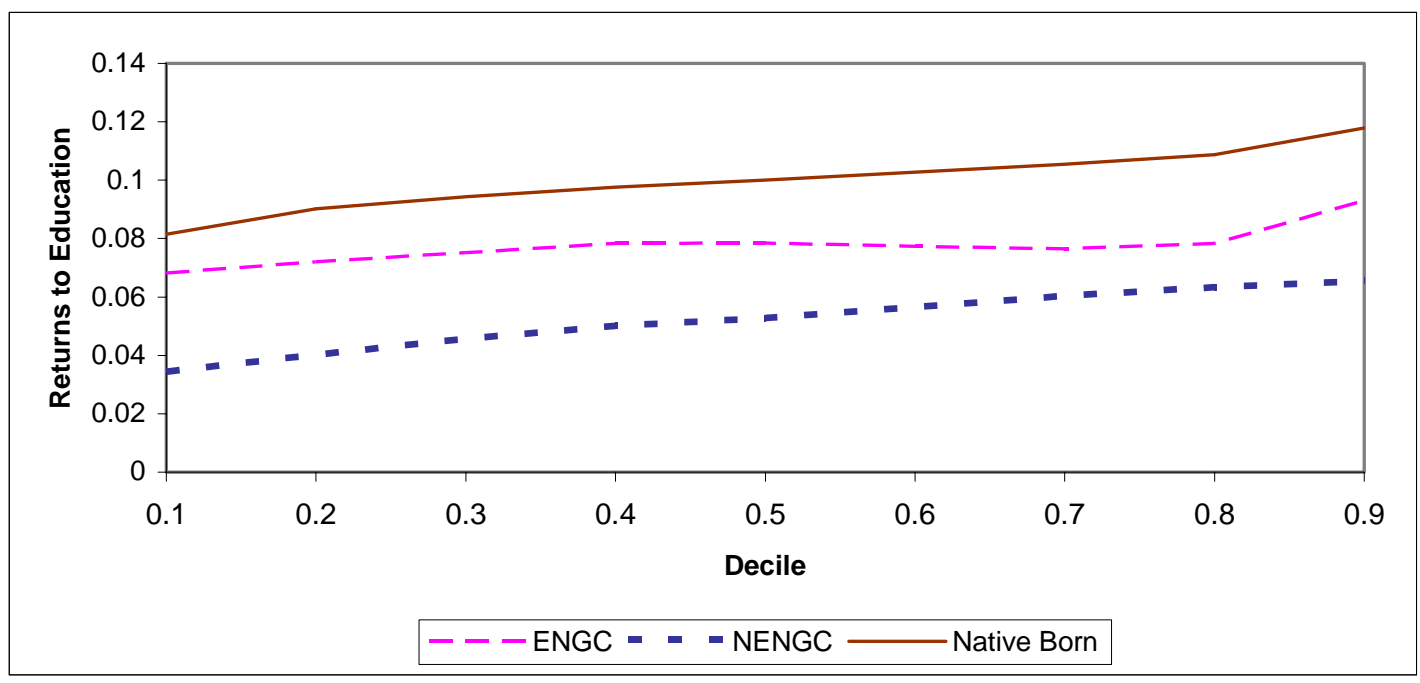

Source: Tables 1, 2 and 3.

Figure 4

Payoffs to Experience by Decile, Adult Males in the U.S., by Nativity, 1999

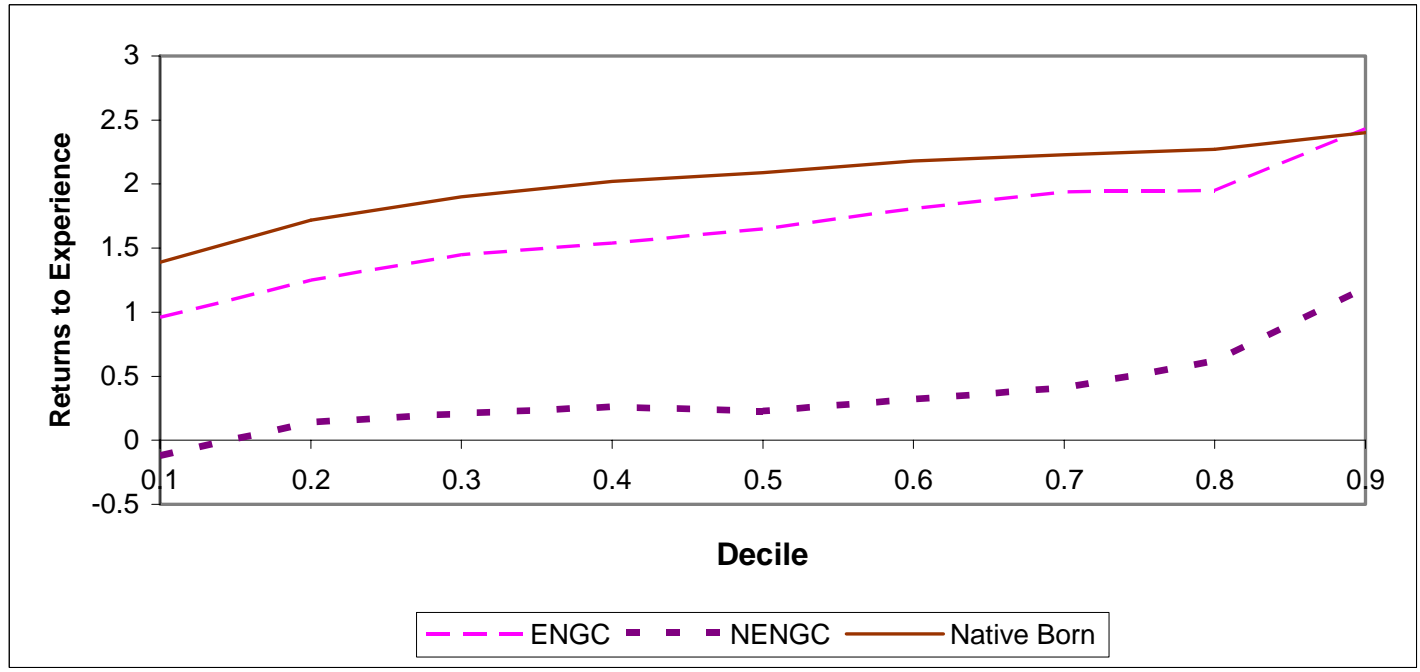

Source: Tables 1, 2 and 3. 
Figure 5

Standardized Wage Differentials of Foreign Born Males Aged 25-64 Years by Decile of the Hourly Wage Distribution Computed from Analyses on

Separate Samples of Native-Born and Foreign-Born Workers, U.S. 1999

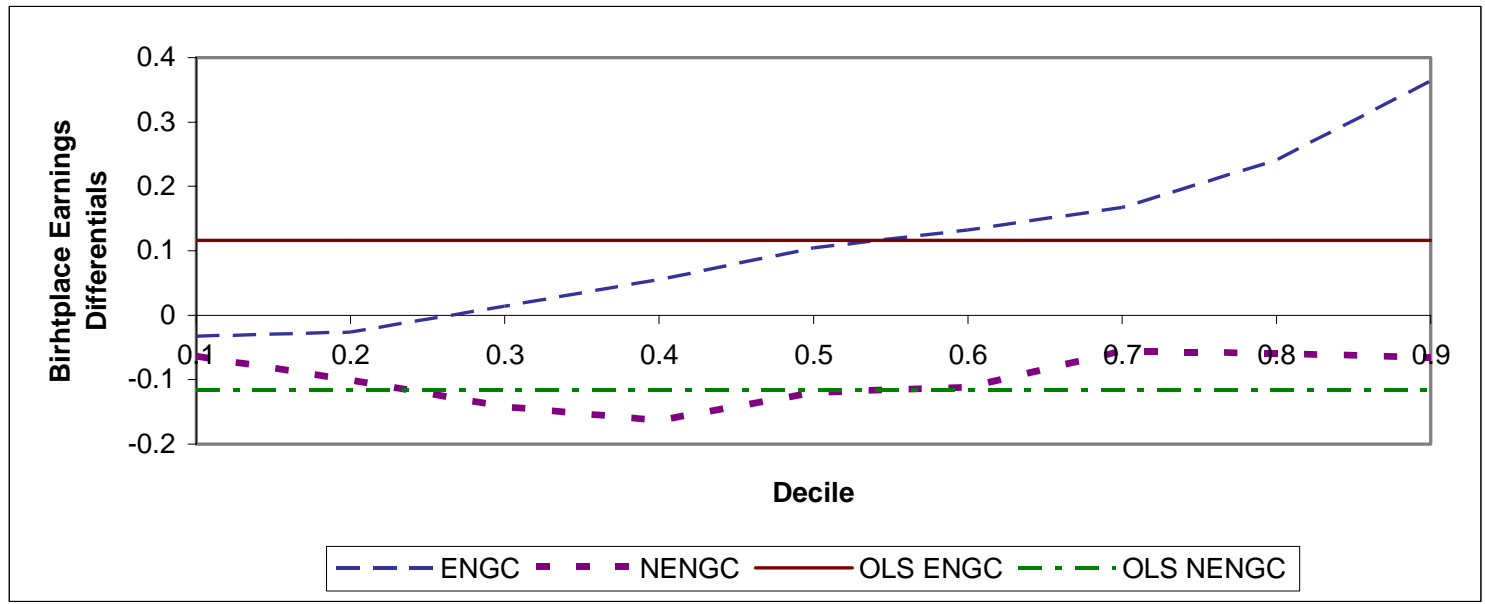

Source: Computations based on estimates in Tables 1, 2 and 3.

Figure 6

Standardized Annual Earnings Differentials of Foreign Born Males Aged 25-64 Years by Decile of the Annual Earnings Distribution Computed from Analyses on Separate Samples of Native-Born and Foreign-Born Workers, U.S. 1999

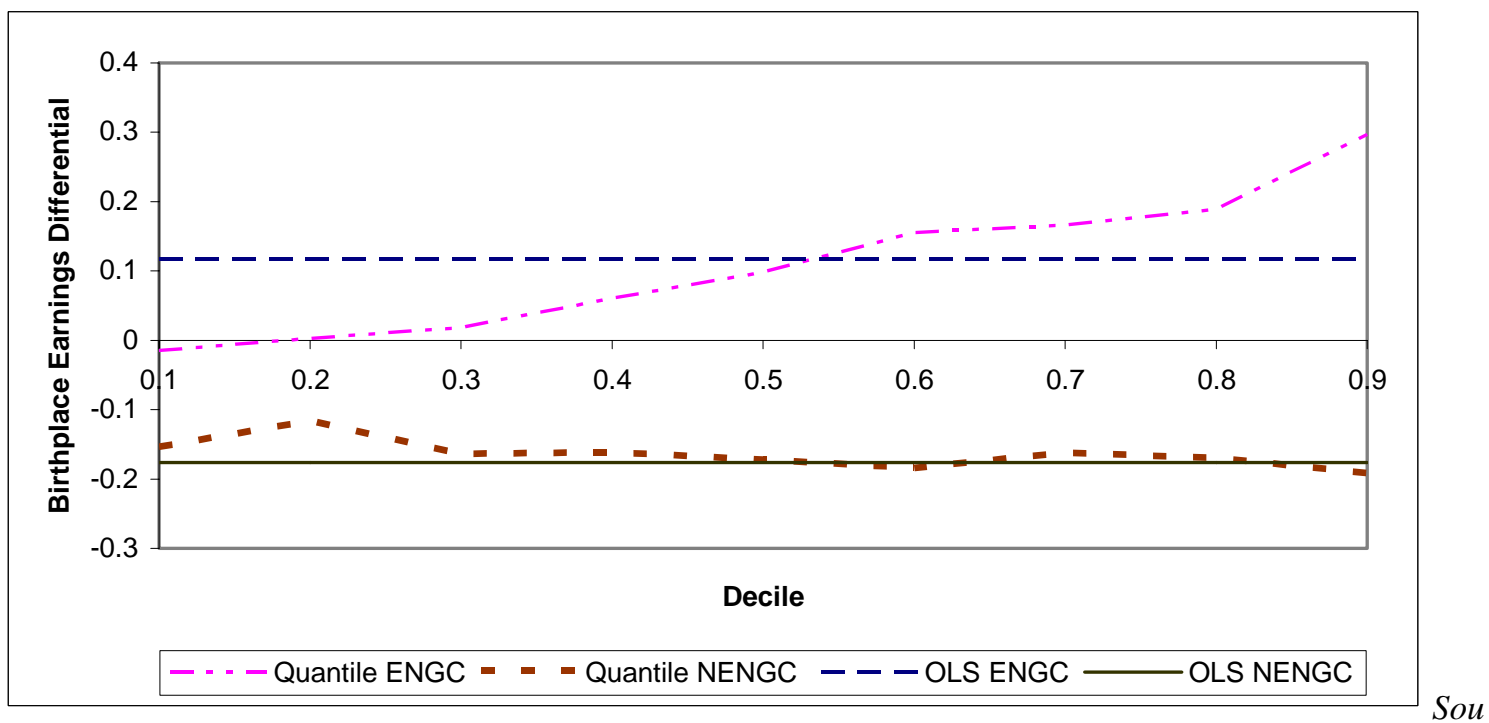

rce: Authors’ computations from the 2000 U.S. Census 1\% PUMS. 
Figure 7

Payoffs to Education by Decile, Adult Males by Nativity, Australia, 2001

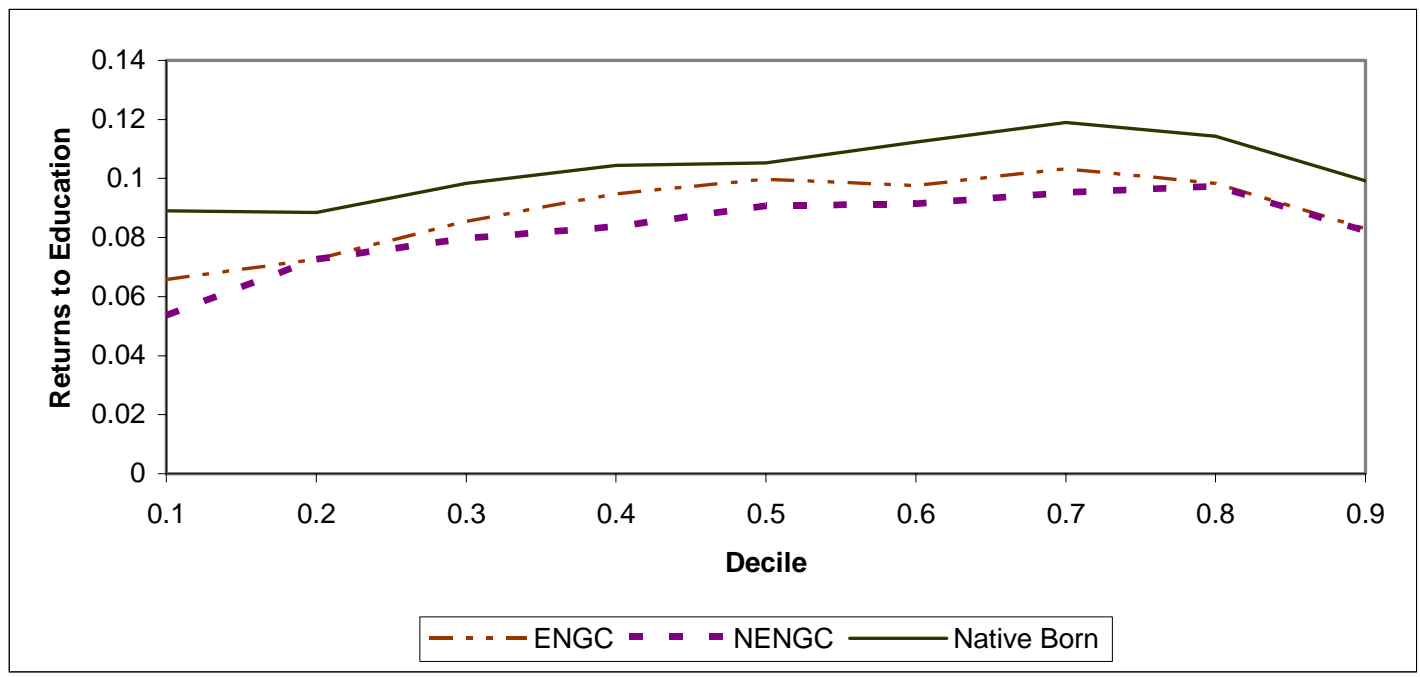

Source: Tables 4, 5 and 6.

Figure 8

Payoffs to Experience by Decile, Adult Males by Nativity, Australia, 2001

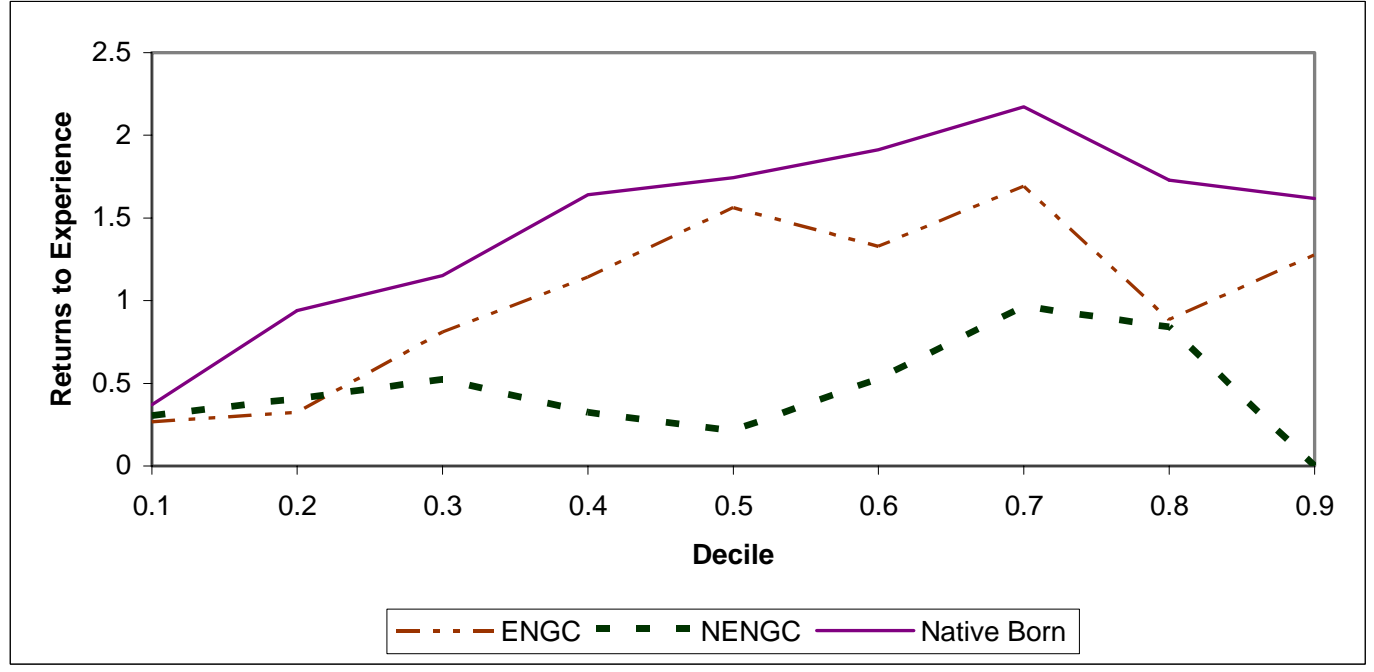

Source: Tables 4, 5 and 6. 


\section{Figure 9}

Standardized Hourly Earnings Differentials of Foreign Born Males Aged 25-64 Years by Decile of the Hourly Earnings Distribution Computed from Analyses on Separate Samples of Native-Born and Foreign-Born Workers, Australia 2001

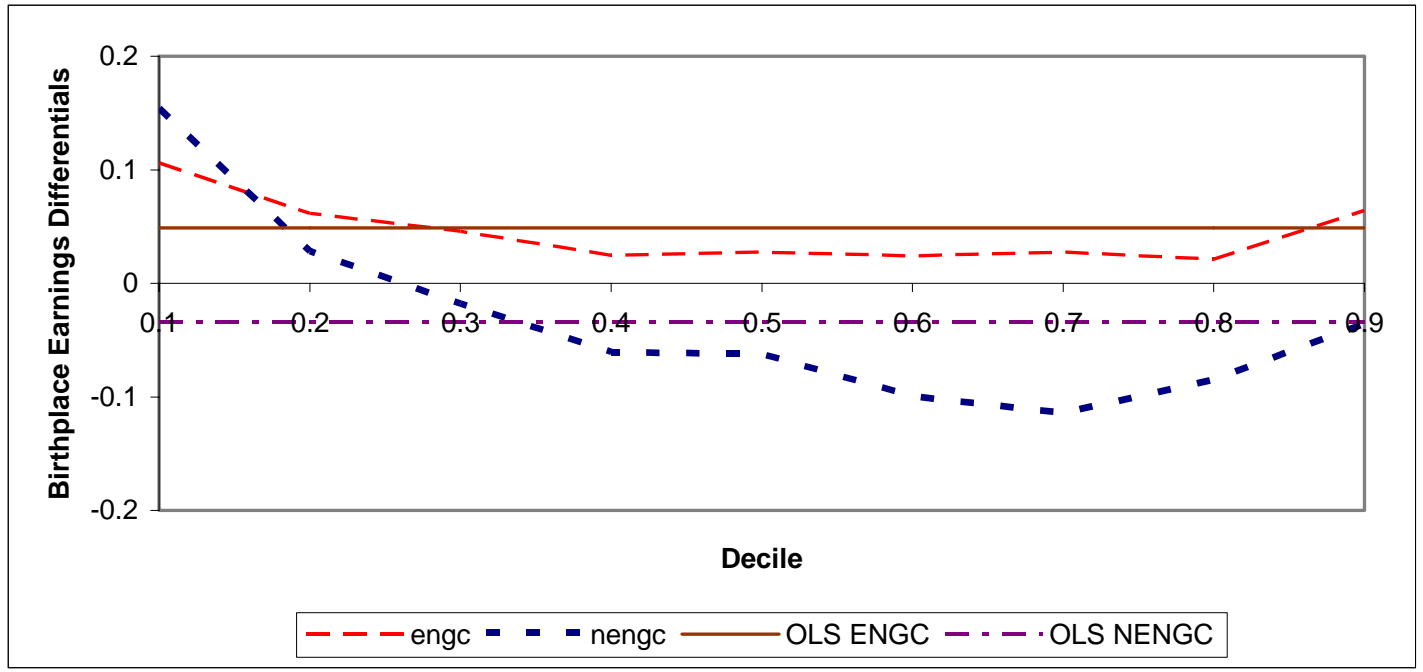

Source: Computations based on estimates in Tables 4, 5 and 6. 